\title{
DYNAMIC EFFECTS OF MONETARY POLICY SHOCKS IN MALAWI
}

\author{
Harold Ngalawa* and Nicola Viegi†
}

\section{Abstract}

This paper sets out to investigate the process through which monetary policy affects economic activity in Malawi. Using innovation accounting in a structural vector autoregressive model, it is established that monetary authorities in Malawi employ hybrid operating procedures and pursue both price stability and high growth and employment objectives. Two operating targets of monetary policy are identified, viz., bank rate and reserve money, and it is demonstrated that the former is a more effective measure of monetary policy than the latter. The study also illustrates that bank lending, exchange rates and aggregate money supply contain important additional information in the transmission process of monetary policy shocks in Malawi. Furthermore, it is shown that the floatation of the Malawi Kwacha in February 1994 had considerable effects on the country's monetary transmission process. In the post-1994 period, the role of exchange rates became more conspicuous than before although its impact was weakened, and the importance of aggregate money supply and bank lending in transmitting monetary policy impulses was enhanced. Overall, the monetary transmission process evolved from a weak, blurred process to a somewhat strong, less ambiguous mechanism.

Keywords: Monetary policy, structural VARs, monetary transmission

\footnotetext{
* Corresponding author: School of Economics and Finance, University of KwaZulu-Natal, Westville Campus, Durban 4000, South Africa. E-mails: ngalawa@ukzn.ac.za; hngalawa@yahoo.co.uk $\uparrow$ School of Economics, University of Pretoria, Lynnwood Road, Pretoria 0002, South Africa. E-mail: nicola.viegi@up.ac.za The authors wish to thank the African Economic Research Consortium (AERC), the Bill \& Melinda Gates Foundation and the Economic Research Southern Africa (ERSA) for financial support.
} 


\subsection{INTRODUCTION}

While it is generally agreed that monetary policy can significantly affect economic activity and prices in the short run and only prices in the long run, considerable debate remains about how monetary policy shocks are transmitted. Views differ with regard to the emphasis placed on money, credit, interest rates, exchange rates, asset prices and the role of commercial banks and other financial institutions (Taylor, 1995). The differences are prevalent even in industrialised countries where the topic has been a subject of research for many years (Kamin, Turner and Van't dack, 1998); and in low income countries such as Malawi, the process is even more uncertain (see Montiel, 1991).

In Malawi, monetary policy plays a prominent role in the management of the country's economy. The Reserve Bank of Malawi (RBM) Act of 1989 outlines the principal objective of the country's central bank as "to implement measures designed to influence the money supply and the availability of credit, interest rates and exchange rates with the view to promoting economic growth, employment (and) stability in prices" (GoM, 1989, pp. 5). Achieving this objective clearly requires an understanding of the process through which monetary policy affects economic activity. There is, however, no study that the authors are aware of that has quantitatively measured the country's monetary transmission process. This paper contributes to the literature by filling this gap. The paper isolates autonomous monetary policy disturbances from other shocks, quantifies their dynamic behaviour and measures the consequent macroeconomic implications in the Malawian economy using a structural vector autoregressive model (SVAR) with short run restrictions. Within the same framework, the study also assesses how the country's monetary transmission process was altered by the RBM's migration from direct to indirect tools of monetary control in the late 1980s and the 1990s.

Since Sims' (1980) pioneering work, VARs and SVARs are considered benchmarks in econometric modelling of monetary policy transmission (Borys and Hovarth, 2007). Among the few studies undertaken on low income countries, Mutoti (2006) employed a cointegrated SVAR to model the monetary transmission process of post-liberalisation Zambia; Maturu (2007) used an SVAR to argue that interest rate and exchange rate channels are unambiguously important channels of monetary policy transmission in Kenya; and Cheng (2006) also used an SVAR to examine the impact of monetary policy shocks on output, prices and the nominal effective exchange rate for Kenya during the period 1977-2005.

In the case of Malawi, there are two theoretical studies, one by Bolnick (1991) and another by Phiri (2002), and no empirical analysis on the country's monetary transmission process. The Bolnick (1991) study was carried out at the time the RBM was converting from direct to indirect tools of monetary management. The study investigated how the changing conditions would weaken or alter links in the country's monetary transmission process. Phiri's (2002) study, on the other hand, carries out a theoretical exposition of transmission channels of monetary policy, and relates them to Malawi's monetary policy framework.

Following this introduction, the rest of the paper is organised as follows: Section 2 is an overview of monetary policy in Malawi since independence in 1964. A methodological framework characterising SVARs, identification of the structural shocks, data sources, variable definitions and measurement of variables is presented in Section 3. Estimation results and inferences are discussed in Section 4. Section 5 presents a summary and conclusions.

\subsection{OVERVIEW OF MONETARY POLICY IN MALAWI SINCE 1964}

Monetary policy in Malawi since independence can be outlined in three broadly distinct monetary policy regimes. This includes a period of financial repression (1964-86), a period of financial reforms (1987-1994) and a period of financial liberalisation (post-1994). At independence in 1964, the formal banking system which the country adopted from the colonial government was perceived to be primarily interested in serving the needs of an expatriate community, to have little interest in direct lending to local entrepreneurs, and to be imposing unreasonably high charges on routine banking services (Gondwe, 2001). To get rid of these 
distortions, direct controls on credit and interest rates were imposed. The agricultural sector, in particular, was accorded preferential lending rates and quota credit allocations in line with the government's policy of promoting agricultural production. Besides these controls, the government also adopted a fixed exchange rate system and imposed price ceilings on selected commodities.

In the late 1970s, a hostile external environment forced the Malawian economy into a deep recession, which persisted through the 1980s. Intensification of civil war in neighbouring Mozambique, the subsequent flooding of refugees into the country, disruption of a cost effective rail route to the Mozambican sea ports of Beira and Nacala, the oil crisis in 1979, and drought in 1980, were some of the factors that triggered the recession. Failure of the economy to adjust to these shocks revealed structural weaknesses in the design of the country's macroeconomic framework. The government was forced, therefore, to adjust their policy from the mid 1980s, moving away from direct to indirect tools of monetary control, among others. A phased financial liberalisation program targeted at enhancing competition and efficiency in the financial sector was adopted.

The reforms commenced with partial deregulation of lending rates in July 1987 and deposit rates in April 1988. The partial deregulation allowed commercial banks to determine their own lending and deposit rates but not to effect any adjustment without prior consultation with the central bank. Credit ceilings were abolished in 1988. In January 1990, the authorities announced the abolition of preferential lending rates to the agricultural sector. Complete deregulation of interest rates was effected in May 1990.

The reform program also overhauled the legal and regulatory framework of the banking system, which involved revision of the RBM Act of 1964 and Banking Act of 1965 in May and December 1989, respectively. While the central bank previously supervised commercial banks only, the revised Banking Act extended its coverage to include non-bank financial institutions (NBFIs), a function that was previously in the hands of the Treasury. In addition, inspection of financial institutions was broadened to include monitoring of adherence to prudential requirements besides compliance to exchange control regulations.

In line with the revised RBM Act, the central bank introduced two new instruments of monetary policy, namely liquidity reserve requirement (LRR) and a discount window facility. The discount window facility led to the introduction of the bank rate, which has since become a very powerful indicator of the stance of monetary policy. A change in the bank rate is usually followed by near instantaneous corresponding changes in both lending and deposit rates. Average yields on government securities also follow the same direction.

The country's financial reforms reached near-completion with the floatation of the Malawian Kwacha on February 7, 1994. Thereafter, the monetary authorities removed exchange control regulations, allowed for the establishment of foreign exchange bureaux, introduced foreign currency denominated accounts, established a forward foreign exchange market and started the trading of foreign exchange options and currency swaps. Ten new commercial banks (one of which has since been liquidated) entered the commercial banking sector between 1994 and January 2010, changing the structure of the market from a duopoly to a fairly competitive sector. The country's first discount house started operations in 1998 followed by a second one in 2002.

The official position of the RBM is that monetary policy in the country utilises a quantitative operating target, reserve money, for monetary policy (Banda, 2004). The rationale for reserve money targeting by the central bank is to balance supply and demand conditions of the monetary aggregate in the money market so as to achieve price stability (Banda, 2004). While the country's monetary policy framework is officially designated as reserve money targeting, the system operates as if the central bank also targets short term interest rates through adjustments in the bank rate. To avoid prejudgement, this study assumes the central bank targets both the bank rate and reserve money and goes on to empirically determine if it is correct that the country employs hybrid operating procedures. 


\subsection{METHODOLOGY}

\section{(a) SVAR Framework}

Suppose Malawi's monetary transmission process is described by a dynamic system whose structural form equation is given by:

$\mathrm{A} y_{t}=\Omega+\Phi_{1} y_{t-1}+\Phi_{2} y_{t-2}+\cdots+\Phi_{p} y_{t-p}+\mathrm{B} \mu_{t}$

where $\mathrm{A}$ is an invertible $(n \times n)$ matrix describing contemporaneous relations among the variables; $y_{t}$ is an $(n \times 1)$ vector of endogenous variables such that $y_{t}=\left(y_{1 t}, y_{2 t}, \ldots, y_{n t}\right) ; \Omega$ is a vector of constants; $\Phi_{i}$ is an $(n \times n)$ matrix of coefficients of lagged endogenous variables $(\forall i=1,2,3, \ldots, p)$; $\mathrm{B}$ is an $(n \times n)$ matrix whose non-zero off-diagonal elements allow for direct effects of some shocks on more than one endogenous variable in the system; and $\mu_{t}$ are uncorrelated or orthogonal white-noise structural disturbances.

The SVAR presented in the primitive system of equations (1) cannot be estimated directly due to the feedback inherent in a VAR process (Enders, 2004). Nonetheless, the information in the system can be recovered by estimating a reduced form VAR implicit in the two equations. Pre-multiplying equation (1) by $\mathrm{A}^{-1}$ yields a reduced form VAR of order $p$, which in standard matrix form is written as:

$y_{t}=\Psi_{0}+\sum_{i=1}^{p} \Psi_{\mathrm{i}} y_{t-i}+\varepsilon_{t}$

where $\Psi_{0}=\mathrm{A}^{-1} \Omega ; \Psi_{\mathrm{i}}=\mathrm{A}^{-1} \Phi_{i}$; and $\varepsilon_{t}=\mathrm{A}^{-1} \mathrm{~B} \mu_{t}$ is an $(n \times 1)$ vector of error terms assumed to have zero means, constant variances and to be serially uncorrelated with all the right hand side variables as well as their own lagged values though they may be contemporaneously correlated across equations. Given the estimates of the reduced form VAR in equation (2), the structural economic shocks are separated from the estimated reduced form residuals by imposing restrictions on the parameters of matrices $A$ and $B$ in equation (3):

$\mathrm{A} \varepsilon_{t}=\mathrm{B} \mu_{t}$

which derives from equation (2). The orthogonality assumption of the structural innovations i.e. $\mathrm{E}\left(\mu_{t}, \mu_{t}^{\prime}\right)=1$, and the constant variance-covariance matrix of the reduced-form equation residuals i.e. $\Sigma=\mathrm{E}\left(\varepsilon_{\mathrm{t}}, \varepsilon_{\mathrm{t}}^{\prime}\right)$ impose identifying restrictions on $A$ and $B$ as presented in equation (4):

$\mathrm{A} \Sigma \mathrm{A}^{\prime}=\mathrm{BB}^{\prime}$

Since matrices $\mathrm{A}$ and $\mathrm{B}$ are both $(n \times n)$, a total of $2 n^{2}$ unknown elements can be identified upon which $n(n+1) / 2$ restrictions are imposed by equation (4). To identify $A$ and $B$, therefore, at least $2 n^{2}-$ $n(n+1) / 2$ or $n(3 n-1) / 2$ additional restrictions are required. These restrictions can be imposed in a number of ways. One approach is to use Sims' (1980) recursive factorisation based on Cholesky decomposition of matrix $A$. The implication of this relationship is that identification of the structural shocks is dependent on the ordering of variables, with the most endogenous variable ordered last (Favero, 2001). In this framework, the system is just (exactly) identified.

While there are many models that are consistent with the recursiveness assumption, the approach is nonetheless controversial (Christiano et al., 1998). The assumptions rationalising the ordering of variables are often different in different studies using the same variables, and since estimation results in a VAR identified by Cholesky factorisation differ with ordering of variables, these studies tend to be incomparable. Changing the order changes the VAR equations, coefficients and residuals, and there are $n$ ! recursive VARs, 
representing all possible orderings (Stock and Watson, 2001). The validity of Cholesky factorisation is also questioned in cases where a simultaneity problem among monetary or macroeconomic variables exists. Following the apparent shortfalls in the approach, many authors have adopted alternative approaches to the identification of structural shocks (see, for example Sims and Zha, 2006; Bernanke and Mihov, 1998; Leeper, Sims and Zha, 1996; Sims, 1986; Bernanke, 1986).

More recent literature has used structural factorisation, an approach which uses relevant economic theory to impose restrictions on the elements of matrices $A$ and $B$ (Sims and Zha, 2006; Bernanke and Mihov, 1998; Sims, 1986; Bernanke, 1986). This study adopts a similar approach. The underlying structural model is identified by assuming orthogonality of the structural disturbances, $\mu_{t}$; imposing that macroeconomic variables do not contemporaneously react to monetary variables, while the contemporaneous feedback in the reverse direction is allowed for; and imposing restrictions on the monetary block of the model reflecting the operational procedures implemented by the monetary policy-maker (Favero, 2001, p.166).

Seven variables are included in our SVAR namely, real output $\left(G Y_{t}\right)$, consumer price level $\left(C P_{t}\right)$, commercial bank lending $\left(B L_{t}\right)$, exchange rates $\left(X R_{t}\right)$, aggregate money supply $\left(M 2_{t}\right)$, bank rate $\left(B R_{t}\right)$ and reserve money $\left(R M_{t}\right)$. Output and consumer prices enter the SVAR as policy goals; bank rate and reserve money as operating targets; and commercial bank lending, exchange rates and monetary aggregates as intermediate targets of monetary policy. The structural shocks in equation (3) are identified according to the following scheme:

$$
\mathrm{A}=\left(\begin{array}{ccccccc}
1 & 0 & 0 & 0 & 0 & 0 & 0 \\
a_{21} & 1 & 0 & 0 & 0 & 0 & 0 \\
a_{31} & a_{32} & 1 & a_{34} & a_{35} & a_{36} & a_{37} \\
a_{41} & a_{42} & 0 & 1 & 0 & 0 & 0 \\
a_{51} & a_{52} & 0 & 0 & 1 & a_{56} & 0 \\
0 & 0 & 0 & a_{64} & 0 & 1 & 0 \\
0 & 0 & a_{73} & a_{74} & a_{75} & a_{76} & 1
\end{array}\right) \quad \varepsilon_{t}=\left(\begin{array}{c}
\varepsilon_{t}^{G Y} \\
\varepsilon_{t}^{C P} \\
\varepsilon_{t}^{B L} \\
\varepsilon_{t}^{X R} \\
\varepsilon_{t}^{M 2} \\
\varepsilon_{t}^{B R} \\
\varepsilon_{t}^{R M}
\end{array}\right)
$$

The first two equations suggest that output and consumer prices are sluggish in responding to shocks to monetary variables in the economy. This scheme is based on the observation that most types of real economic activity may respond only with a lag to monetary variables because of inherent inertia and planning delays (Bernanke and Mihov, 1997; Karame and Olmedo, 2002; Becklemans, 2005; Vonnak, 2005; Cheng, 2006).

Commercial bank lending are postulated to be contemporaneously affected by all variables in the system. Blundell-Wignall and Gizycki (1992) argue that expectations of future activity form an important determinant of credit demand. Assuming current output, price level, exchange rates, interest rates, and money supply give some indication of what is expected in the future (Becklemans, 2005) and because economic agents are indeed forward looking, bank lending may respond contemporaneously to all variables in the system.

Modelling contemporaneous responses of exchange rates to other variables in an SVAR is relatively standard across studies. Since the exchange rate is a forward-looking asset price, most studies assume that all variables have contemporaneous effects on the exchange rate (Kim and Roubini, 2000). Becklemans (2005) uses a real trade-weighted exchange rate index in a study of Australia and assumes that the index responds instantaneously to all variables in the system. In a study of Kenya, Cheng (2006) employs a nominal effective exchange rate and maintains that the exchange rate responds contemporaneously to all variables in the SVAR. 
Similarly, Borys and Hovarth (2007) in a study of the Czech Republic and Piffanelli (2001) in a study of Germany assume all variables in the system affect exchange rates instantaneously.

In Malawi, however, the instantaneous response of exchange rates to all macroeconomic variables cannot be justified. The financial sector in the country lacks depth and is weakly integrated into global markets. It is safe, therefore, to assume that information delays will be prevalent, forcing players in the foreign exchange market to respond with a lag to changes in interest rates, bank lending and monetary aggregates. This study, therefore, departs from the previous studies and postulates that exchange rates respond contemporaneously to changes in the level of output and consumer prices only and with a lag to movements in interest rates, bank lending and monetary aggregates.

Given the large dimensionality of the problem, the study avoids the temptation to add more variables to the SVAR to capture external factors. The complete SVAR analysed in this study has seven variables, which is already large by SVAR standards and increasing the number of variables without proper justification would only decrease the power of the model without making meaningful additions to the output. The study maintains, nonetheless, that exchange rates, besides being an asset price, should also account for movements in external factors such as oil prices and interest rates on the international market. Accordingly, the study does not expect a loss of information on developments in the external sector.

The fifth equation is a standard money demand function. The equation postulates that demand for money in the country makes aggregate money supply respond contemporaneously to changes in consumer prices, output and interest rates but not to changes to other variables in the system, akin to Sims and Zha (1998). The last two equations constitute the monetary policy feedback rule, which draws on the assumption that the country employs hybrid operating procedures, with the bank rate and reserve money as operating targets of monetary policy. In this framework, both interest rates and reserves are expected to contain information about monetary policy (Bernanke and Mihov, 1997). The country's effective operating target, accordingly, is determined empirically.

The monetary policy feedback rule is drawn on the assumption that information delays impede policymakers' ability to react immediately to economic activity and price level developments (Karame and Olmedo, 2002). Both the bank rate and reserve money, therefore, do not respond immediately to output and consumer prices. The bank rate, specifically, responds contemporaneously to changes in the exchange rates only. While exchange rate data is available real-time, data on other variables including bank lending and monetary aggregates is usually available to the monetary authorities with a lag. Reserve money, on the other hand, is assumed to respond contemporaneously to all monetary variables because by its definition, this information is inherent in the monetary aggregate.

\section{(b) Analysis}

Analysis of the SVAR is carried out in three modular experiments. First, a generic model comprising the country's monetary policy goals and operating targets is estimated. Output and price level enter the model as policy goals while bank rate and reserve money go in as operating targets. The rationale for estimating the generic model is to establish how the two monetary policy goals respond to each of the operating targets and to find out if monetary authorities react to changes in the policy goals. In addition, the estimated generic model is used to identify which of the two monetary policy operating targets has a greater impact on the policy goals.

At the second level of analysis, bank lending, exchange rates and M2, representing three different transmission processes, are separately appended to the generic model and estimated. Following Disyatat and Vongsinsirikul (2003) and Morsink and Bayoumi (2001), two sets of impulse responses are calculated in each case: one with the variable of interest endogenised and the other with the variable exogenised. The latter procedure generates an SVAR identical to the former, except that it blocks off any responses within the SVAR that pass through the variable of interest (Disyatat and Vongsinsirikul, 2003). The two sets of impulse 
responses are later compared. The size of the difference in the impulse responses is an indicator of the level of information contained in the variable of interest associated with a particular transmission channel. Large differences denote more information in the variable of interest and suggest greater importance of the related transmission channel.

At the third and final level of analysis, all variables found to hold important information in the country's monetary transmission process are pooled and a composite SVAR is estimated. A general identification scheme based on short run restrictions developed in system of equations (5) is used for identifying structural shocks in each of the models.

\section{(c) Data, Data Sources and Measurement of V ariables}

The study employs monthly time series data for the period 1988:1 to 2005:12. The starting date has been chosen to capture the period when monetary authorities in Malawi migrated from using direct measures of monetary control to using indirect measures. Major sources of data include the RBM, the National Statistical Office (NSO) of Malawi, the Malawi Meteorological Department and the University of Malawi.

Bank rate $\left(B R_{t}\right)$ is defined as the rate at which the central bank provides short term loans to commercial banks and discount houses in its function as a lender of last resort. The variable enters the SVAR as an instrument target of monetary policy. Reserve money $\left(R M_{t}\right)$ is also employed as an instrument target of monetary policy in the SVAR. Components of $R M_{t}$ are identified as total cash reserves held by the central bank, vault cash in commercial banks and currency held by the non-bank public. The variable $B L_{t}$ captures commercial bank lending and advances and it enters the SVAR as an intermediate target of monetary policy. Similarly, exchange rate $\left(X R_{t}\right)$ enters the SVAR as an intermediate target of monetary policy. Middle nominal exchange rates of the Malawian Kwacha vis-à-vis the United States Dollar (USD) are used as a proxy for $X R_{t}$. Aggregate money supply (M2) is measured by the sum of currency in circulation, demand deposits and time deposits. The variable also enters the SVAR as an intermediate target of monetary policy.

Consumer prices $\left(C P_{t}\right)$ are measured by the all items national composite consumer price index with base year 2000. The variable enters the SVAR as a monetary policy goal. A measure of real output $\left(G Y_{t}\right)$ enters the SVAR as a monetary policy goal as well. GDP data used as a proxy for $G Y_{t}$ for Malawi is, however, only available in annual frequency. This presents a case for interpolation. Several studies have used interpolated monthly GDP series in SVARs (see, for example, Cheng, 2006; Borys and Hovarth, 2007). This study employs the Friedman method of interpolating time series by related series to compute the required monthly GDP series from annual data.

The Friedman method of interpolating time series by related series employs log-linear interpolations of a vector of variables $X_{t}$, which are available in both annual and monthly frequency, that explain the variable of interest $Y_{t}$, to compute actual errors in the trend interpolation for the elements of $X_{t}$. These errors are then used to adjust the linear trend interpolation for $Y_{t}$ by the weighted individual error in trend interpolation for each regressor, where the weights are given by the respective coefficients on the $X_{j t}$ variable in the annual regression of $X_{t}$ on $Y_{t}$ (see Friedman, 1962).

All variables, with the exception of interest rates, are expressed in natural logarithms. They are also seasonally adjusted using TRAMO (Time Series Regression with Autoregressive Moving Average (ARIMA) Noise, Missing Observations, and Outliers) and SEATS (Signal Extraction in ARIMA Time Series) with a forecast horizon of 12 months. The variables are further subjected to a test for stationarity, which reveals that they are all I(1). The study, however, proceeds with estimation of the SVAR in levels consistent with standard practice anchored on the canonical paper of Sims, Stock and Watson (1990). The Sims et al. (1990) paper demonstrates in part that the common practice of attempting to transform models to stationary form by difference or cointegration operators whenever it appears likely that the data are integrated is unnecessary 
because statistics of interest often have distributions that are unaffected by nonstationarity, which suggests that hypotheses can be tested without first transforming to stationary regressors.

The findings of Sims et al. (1990) have been generally accepted and widely adopted in the SVAR literature (Bernanke and Mihov, 1996; Piffanelli, 2001; Dungey and Pagan, 2000; Kim, 1999; Brichetto and Voss, 1999; Bernanke and Mihov, 1998; Ramaswamy and Sloek, 1998; Sims, 1992). The preference of SVARs in levels, according to Kim and Roubini (2000) and Becklelmans (2005), can be explained, at least in part, by a reluctance to impose possibly incorrect restrictions on the model. Kim and Roubini (2000) stress that if false restrictions are imposed, the resulting inferences will be incorrect as well. In addition, Bernanke and Mihov (1996) point out that the levels specification yields consistent estimates whether cointegration exists or not, whereas a differences specification is inconsistent if some variables are cointegrated.

\subsection{ESTIMATES AND INFERENCES}

\section{(a) Generic Model}

Investigation of the monetary transmission process commences with a simple four variable generic model. The vector of endogenous variables included in the model is presented as:

$y_{t}^{\prime}=\left[G Y_{t}, C P_{t}, B R_{t}, R M_{t}\right]$

Following the identification scheme in system of equations (5), the equation separating structural economic shocks from the estimated reduced form residuals for the generic model is presented as:

$$
\left(\begin{array}{cccc}
1 & 0 & 0 & 0 \\
a_{21} & 1 & 0 & 0 \\
0 & 0 & 1 & 0 \\
0 & 0 & a_{43} & 1
\end{array}\right)\left(\begin{array}{c}
\varepsilon_{t}^{G Y} \\
\varepsilon_{t}^{C P} \\
\varepsilon_{t}^{B R} \\
\varepsilon_{t}^{R M}
\end{array}\right)=\left(\begin{array}{cccc}
b_{11} & 0 & 0 & 0 \\
0 & b_{22} & 0 & 0 \\
0 & 0 & b_{33} & 0 \\
0 & 0 & 0 & b_{44}
\end{array}\right)\left(\begin{array}{c}
\mu_{t}^{G Y} \\
\mu_{t}^{C P} \\
\mu_{t}^{B R} \\
\mu_{t}^{R M}
\end{array}\right)
$$

Selection of the optimal lag length is guided by established criteria (Akaike, Hannan-Quinn and Schwartz Information Criteria), which suggest a lag length of two (this approach is applied in all subsequent models). At the chosen lag length (of order two), all the eight inverse roots of the characteristic autoregressive (AR) polynomial have modulus less than one and lie inside the unit circle, indicating that the estimated VAR is stationary or stable. A VAR lag exclusion Wald test further reveals that all endogenous variables in the model are jointly significant at each of the lag lengths for all equations collectively. Separately, at lag length of order one, all the endogenous variables are jointly significant in all equations while at lag length of order two, the endogenous variables are jointly significant in all equations except in the consumer price equation.

Before making inferences on the structural shocks in the model, the study analyses correlations between movements in the bank rate and reserve money and their corresponding recovered structural shocks to ascertain if the monetary policy shocks are reasonable. It is observed that there is some correlation in the movements of the recovered bank rate and reserve money structural innovations, on the one hand, and the month-on-month growth rates of the bank rate and reserve money, respectively, on the other (plots not presented here but available on request). The correlations are, however, more pronounced between the bank rate and its recovered structural shocks compared to reserve money and its recovered structural shocks. Reliability of the structural shocks is also ascertained by assessing the efficiency of the structural coefficients estimated in the SVAR. All structural estimates of the coefficients in matrices A and B of the generic model show up with standard errors that are less than one, implying that the coefficients are efficient.

Next the study analyses the response of the central bank to shocks in the policy goals. Figure 1 presents impulse responses of the bank rate and reserve money to structural one standard deviation 
innovations in output and consumer prices over a five-year horizon. Impulse responses of output and consumer prices to own shocks are also presented in the same figure. The time scale measured on the primary horizontal axis is in months and the dashed lines represent analytic confidence intervals obtained from variance-covariance matrices after the final iteration. Both an output shock corresponding to an unanticipated 11 percent increase in output and a consumer price shock equivalent to an unexpected 2.2 percent rise in consumer prices trigger significant responses by the central bank, illustrating that monetary authorities in Malawi are concerned with both inflation and economic growth in line with the RBM Act of 1989. The bank responds to the output shock by loosening monetary policy through a decrease in the bank rate to further buoy the output growth. In response to the consumer price shock, monetary policy is tightened by raising the bank rate to arrest the increase in the consumer prices. The central bank's response with regard to reserve money, however, is surprising. Following the sudden increase in output, reserve money declines while the unexpected rise in consumer prices triggers an increase in reserve money.

[insert Figure 1 here]

Economic theory posits that an increase in output is associated with a corresponding increase in income, aggregate demand, and money supply. However, the monetary authorities may have been reducing reserve money (following an economic expansion) to keep money supply and hence inflation under control. The theory also suggests that monetary authorities normally respond to an increase in consumer prices with a contractionary monetary policy. In the case of Malawi, however, the monetary authorities may have been increasing money supply following higher consumer prices as a way of validating the condition.

To analyse how monetary policy goals are affected by shocks to the operating targets, impulse responses of output and consumer prices to structural one standard deviation shocks in the bank rate and reserve money are plotted. Figure 2 reveals that a monetary policy shock corresponding to an unanticipated increase in the bank rate of about 2.2 percent leads to a decline in output, which bottoms out after 5 months at 1.4 percent below baseline. The price level, however, responds to monetary tightening by increasing, although insignificantly, which is maintained even after five years. This finding, referred to as the price puzzle,' is common in the literature (Weitong, 2007; Kugler, Jordan, Lenz and Savios, 2004; Disyatat and Vongsinsirikul, 2003; Piffanelli, 2001; Mihira and Sugihara, 2000; Clarida and Gertler, 1996; Bernanke and Mihov, 1997; and Sims, 1992).

\section{[insert Figure 2 here]}

Several explanations to the price puzzle have been suggested. Disyatat and Vongsinsirikul (2003) argue that failure to include a rich enough specification of the information available to policy makers is what causes the puzzle to show up. They maintain that if policy makers are able to observe variables that contain useful information about future prices, but those variables are left out of the model, a monetary tightening may be associated with higher prices because they partly reflect systematic policy responses to information indicating that inflation is on the way. Empirical evidence, however, does not support the Disyatat and Vongsinsirikul (2003) hypothesis. In a study of this phenomenon in Germany, Sims (1992) added a number of variables, including commodity prices and exchange rates in his system of equations to control for unanticipated future inflation after he had encountered the price puzzle. However, the perverse price response persisted. Piffanelli (2001) argues that the price puzzle may occur if an incorrect operating target is used in the analysis. In her study of Germany, Piffanelli (2001) showed that the price puzzle appears when the call rate is used and it disappears when the Lombard rate is used. A similar finding is reported by Bernanke and Mihov (1997)1.

\footnotetext{
${ }^{1}$ We have followed the literature and experimented with a series of commodity prices and food price to deal with the prize puzzle without success. These results are available on request.
} 
Figure 2 also shows that an expansionary monetary shock equivalent to a sudden 7.6 percent increase in reserve money causes an increase in output, peaking at 1.4 percent above baseline after 15 months. The price puzzle also shows up when reserve money is used as an operating target. Consumer prices respond to the unexpected increase in reserve money with an increase which peaks at 0.4 percent above baseline after 10 months. The response is nonetheless insignificant.

Overall, shocks to either of the monetary policy operating targets attract significant output responses and insignificant consumer price responses, suggesting that monetary factors may not be primary determinants of inflation in Malawi. This finding is supported by the preponderant weight of food costs (58.1 percent) in the representative basket of commodities used for measuring national consumer price indices, which indicates that structural rigidities in food production may be a more important cause of inflation than monetary variables. To determine the relative importance of each structural innovation in explaining fluctuations of the variables in the generic model, Table 1 presents variance decompositions for each variable in the model over a five-year forecast horizon. Given the two policy goals, fluctuations in both the bank rate and reserve money are dominated by a shock in consumer prices, reflecting that the principal objective of monetary policy in the country is price stability. While shocks to consumer prices account for 13.1 percent of the bank rate fluctuations after 6 months, 18.6 percent after a year and 21.9 percent after 2 years, output shocks account for 8.2 percent of the bank rate fluctuations after 6 months, 14.7 percent after a year and 17.4 percent after 2 years. Shocks to consumer prices also account for 3.4 percent of the reserve money fluctuations after 6 months, 10.7 percent after a year and 25.5 percent after 2 years while shocks to output account for 4.8 percent of the reserve money fluctuations after 6 months, 9.8 percent after a year and 16.3 percent after two years.

\author{
[insert Table 1 here]
}

Table 1 also reveals that the difference in the proportion of fluctuations in output attributed separately to the bank rate and reserve money is not pronounced. The bank rate, however, accounts for a notably larger proportion of the fluctuations in consumer prices than reserve money. On the whole, the preliminary indication is that the bank rate is a more effective tool of monetary policy than reserve money. While bank rate shocks account for 4.9 percent of the fluctuations in output after 6 months, 7.8 percent after a year, 5.8 percent after 2 years and 6 percent after five years, reserve money shocks account for 0.6 percent of the output fluctuations after 6 months, 3.5 percent after a year, 8 percent after 2 years and 4.1 percent after 5 years. This shows that interest rate shocks account for a larger proportion of the fluctuations in output up to a year and, thereafter, reserve money shocks are responsible for most of the variations in output. Reserve money shocks account for only 0.9 percent of the fluctuations in consumer prices after 6 months, 1.1 percent after two years and 0.5 percent after 4 years while bank rate shocks account for 0.7 percent of the fluctuations in consumer prices after 6 months, 3.7 percent after 2 years and 7.7 percent after 4 years, illustrating that the bank rate accounts for most of the consumer price variations given the two operating targets.

\title{
(b) Channels of Monetary Transmission
}

In order to unfold the monetary transmission process, analysis moves away from the generic model to an examination of more specific transmission channels. Three channels are investigated: the bank lending channel, the exchange rate channel and the money effect channel. In the course of identifying major monetary transmission channels for Malawi, the study concentrates on measuring the importance of each channel in the transmission process.

\section{(i) The Bank Lending Model}

The bank lending model is a component of the credit channel of monetary transmission, where the underlying argument is that asymmetric information and costly enforcement of contracts create agency problems in financial markets (Bernanke and Gertler, 1995). Of the two mechanisms that explain this approach, the balance sheet model (not pursued further in this study due to data constraints) describes 
monetary transmission through either equity prices or interest rates and firms' cash-flows operating via the net worth of business firms (Mishkin, 1995)

The bank lending model, on the other hand, operates through quantity rather than price of credit. A monetary policy shock is assumed to be transmitted through changes in bank reserves, the total amount of available bank credit, and bank lending. The channel presumes that firms facing informational frictions in financial markets rely on bank lending for external finance because it is prohibitively expensive for them to issue securities in the open market (Disyatat and Vongsinsirikul, 2003). A decline in available bank credit, therefore, adversely affects investments and output. Appending commercial bank lending to equation (6) transforms the generic model to a bank lending model and the corresponding vector of endogenous variables becomes:

$y_{t}^{\prime}=\left[G Y_{t}, C P_{t}, B L_{t}, B R_{t}, R M_{t}\right]$

The SVAR under investigation in equation (8) comprises five variables, which include output, consumer prices, bank lending, bank rate and reserve money. In line with the identification scheme in system of equations (5), the bank lending model is identified according to the following scheme:

$$
\left(\begin{array}{ccccc}
1 & 0 & 0 & 0 & 0 \\
a_{21} & 1 & 0 & 0 & 0 \\
a_{31} & a_{32} & 1 & a_{34} & a_{35} \\
0 & 0 & 0 & 1 & 0 \\
0 & 0 & a_{53} & a_{54} & 1
\end{array}\right)\left(\begin{array}{l}
\varepsilon_{t}^{G Y} \\
\varepsilon_{t}^{C P} \\
\varepsilon_{t}^{B L} \\
\varepsilon_{t}^{B R} \\
\varepsilon_{t}^{R M}
\end{array}\right)=\left(\begin{array}{ccccc}
b_{11} & 0 & 0 & 0 & 0 \\
0 & b_{22} & 0 & 0 & 0 \\
0 & 0 & b_{33} & 0 & 0 \\
0 & 0 & 0 & b_{44} & 0 \\
0 & 0 & 0 & 0 & b_{55}
\end{array}\right)\left(\begin{array}{l}
\mu_{t}^{G Y} \\
\mu_{t}^{C P} \\
\mu_{t}^{B L} \\
\mu_{t}^{B R} \\
\mu_{t}^{R M}
\end{array}\right)
$$

Figure 3 presents impulse responses of output, consumer prices and bank lending to innovations in the bank rate, reserve money and bank lending. The figure shows that a bank rate shock equivalent to an unexpected 2.2 percent increase in the bank rate causes bank lending to decline, bottoming out at 2 percent below baseline after 18 months. This response is significant between 6 and 24 months. A reserve money shock, on the other hand, corresponding to a 7.2 percent sudden increase in reserve money leads to an increase in bank lending, peaking at 1.5 percent above baseline after 3 years. This response, however, is not significant. An unexpected 5.5 percent rise in bank lending, on the other hand, leads to an increase in both output and consumer prices. To determine the importance of the bank lending channel, impulse responses of consumer prices and output to bank rate and reserve money shocks are plotted in each case with two scenarios: endogenous and exogenous bank lending. The case of exogenous bank lending blocks off responses that pass through bank lending while the case of endogenous bank lending allows bank lending to transmit the monetary policy shocks.

\section{[insert Figure 3 here]}

Figure 4 shows that in all four instances, there is a considerable difference in the size of impulse responses when bank lending is exogenous and when it is endogenous. This provides preliminary evidence that bank lending contains important additional information in the country's monetary transmission process.

\section{[insert Figure 4 here]}

In line with theoretical expectations, output decreases following a sudden increase in the bank rate and increases following an unexpected increase in reserve money while consumer prices go up in response to an unanticipated increase in reserve money. The response of consumer prices to an unexpected rise in the bank rate continues to show the price puzzle, dissipating faster though when bank lending is endogenous. 
Taylor (1995), Obstefield and Gertler (1995) and others have drawn attention to monetary policy operating through exchange rates and net exports. Monetary policy can influence the exchange rate through interest rates, direct intervention in the foreign exchange market or inflationary expectations. The changes in the exchange rate, in turn, affect aggregate demand through the cost of imported goods, the cost of production and investment, international competitiveness and firms' balance sheets in the case of high liability dollarisation (Dabla-Norris and Floerkemeier, 2006).

Summarising the channel, Ireland (2005) states that when domestic nominal interest rates increase above their foreign counterparts, equilibrium in the foreign exchange market requires that the domestic currency gradually depreciate at a rate that serves to equate the risk adjusted returns on various debt instruments denominated in each of the two currencies. This expected future depreciation requires an initial appreciation of the domestic currency that, when prices are slow to adjust, makes domestically produced goods more expensive than foreign produced goods leading to a fall in net exports, domestic output and employment (Ireland, 2005).

The exchange rate channel is expected to have important effects on output and inflation in Malawi due to the relatively large proportion of imports in the country's GDP, estimated at 44 percent in 2006 (see Reserve Bank of Malawi, 2007). On the other hand, the channel may be weakened by the fact that the country's holdings of foreign reserves is usually low (about 2.7 months of import cover on average in 2005) and may not be enhanced by higher domestic interest rates due to a low interest elasticity of foreign capital flows. The study investigates the importance of the channel in Malawi's monetary transmission process by appending the exchange rate variable $X R_{t}$, to the generic model. The vector of endogenous variables in the exchange rate model is, accordingly, presented as follows:

$y_{t}^{\prime}=\left[G Y_{t}, C P_{t}, X R_{t}, B R_{t}, R M_{t}\right]$

The five variables in the model are output, consumer prices, exchange rates, bank rate and reserve money. In line with the system of equations (5), the model is identified according to the following scheme:

$$
\left(\begin{array}{ccccc}
1 & 0 & 0 & 0 & 0 \\
a_{21} & 1 & 0 & 0 & 0 \\
a_{31} & a_{32} & 1 & 0 & 0 \\
0 & 0 & a_{43} & 1 & 0 \\
0 & 0 & a_{53} & a_{54} & 1
\end{array}\right)\left(\begin{array}{c}
\varepsilon_{t}^{G Y} \\
\varepsilon_{t}^{C P} \\
\varepsilon_{t}^{X R} \\
\varepsilon_{t}^{B R} \\
\varepsilon_{t}^{R M}
\end{array}\right)=\left(\begin{array}{ccccc}
b_{11} & 0 & 0 & 0 & 0 \\
0 & b_{22} & 0 & 0 & 0 \\
0 & 0 & b_{33} & 0 & 0 \\
0 & 0 & 0 & b_{44} & 0 \\
0 & 0 & 0 & 0 & b_{55}
\end{array}\right)\left(\begin{array}{c}
\mu_{t}^{G Y} \\
\mu_{t}^{C P} \\
\mu_{t}^{X R} \\
\mu_{t}^{B R} \\
\mu_{t}^{R M}
\end{array}\right)
$$

Figure 5 presents impulse responses of exchange rates to own, bank rate and reserve money shocks and responses of output and consumer prices to innovations in exchange rates. A monetary tightening corresponding to an unexpected 2.2 percent increase in the bank rate causes the domestic currency to appreciate, moving 1.5 percent below baseline after 3 years. The response, however, is insignificant. Contrary to theoretical expectations, the exchange rate responds to a reserve money shock equivalent to a 7.6 percent sudden increase in reserve money with an appreciation, moving 1 percent below baseline after a year. This response is also insignificant.

\section{[insert Figure 5 here]}

An exchange rate shock equivalent to a depreciation of the domestic currency by 5.5 percent, however, attracts significant responses in both consumer prices and output. Consumer prices rise, peaking at 4 percent above baseline after 3 years while output declines in the first 4 months and rises thereafter, peaking at 4.3 percent above baseline after 4 years. 
In spite of the weak responses of exchange rates to innovations in monetary policy operating targets, Figure 6 demonstrates that impulse responses of output and consumer prices to bank rate and reserve money shocks are different when exchange rates are exogenous compared to when they are endogenous, indicating that inclusion of the exchange rate provides important additional information to the monetary transmission process.

[insert Figure 6 here]

(iii) The Money Effect Model

An alternative channel of monetary transmission is the monetarist view. The channel downplays the role of interest rates and liquid asset adjustment in the transmission mechanism, reducing the process to a direct link between changes in aggregate money supply and absorption (Bolnick, 1991). According to this view, prices and output respond to monetary impulses because households and businesses fail to anticipate or perceive correctly all of the future implications of past and current actions (Meltzer, 1995). These misperceptions occur primarily because of the existence of a time lag between observing the impulses and being able to distinguish between permanent and transitory impulses and real and nominal shocks. A monetary shock, therefore, drives a wedge between money supply and money demand, which triggers adjustments in portfolio holdings that in turn alter spending decisions. The study uses aggregate money supply (M2) as an indicator of the money effect. Appending $M 2_{t}$ to the generic model, the vector of endogenous variables in the money effect model is presented as:

$y_{t}^{\prime}=\left[G Y_{t}, C P_{t}, M 2_{t}, B R_{t}, R M_{t}\right]$

where the five variables in the model are output, consumer prices, M2, bank rate and reserve money. Following the identification scheme in system of equations (5), the model is identified as:

$$
\left(\begin{array}{ccccc}
1 & 0 & 0 & 0 & 0 \\
a_{21} & 1 & 0 & 0 & 0 \\
a_{31} & a_{32} & 1 & a_{34} & 0 \\
0 & 0 & 0 & 1 & 0 \\
0 & 0 & a_{53} & a_{54} & 1
\end{array}\right)\left(\begin{array}{c}
\varepsilon_{t}^{G Y} \\
\varepsilon_{t}^{C P} \\
\varepsilon_{t}^{M A} \\
\varepsilon_{t}^{B R} \\
\varepsilon_{t}^{R M}
\end{array}\right)=\left(\begin{array}{ccccc}
b_{11} & 0 & 0 & 0 & 0 \\
0 & b_{22} & 0 & 0 & 0 \\
0 & 0 & b_{33} & 0 & 0 \\
0 & 0 & 0 & b_{44} & 0 \\
0 & 0 & 0 & 0 & b_{55}
\end{array}\right)\left(\begin{array}{l}
\mu_{t}^{G Y} \\
\mu_{t}^{C P} \\
\mu_{t}^{M 2} \\
\mu_{t}^{B R} \\
\mu_{t}^{R M}
\end{array}\right)
$$

Figure 7 presents impulse responses of M2 to own, bank rate and reserve money shocks and responses of output and consumer prices to M2 shocks. A monetary tightening equivalent to an unexpected 2.2 percent increase in the bank rate leads to a significant increase in M2. A reserve money shock corresponding to a sudden 7.2 percent increase in reserve money, however, triggers no response in M2. A possible explanation for this occurrence is the dominance of commercial banks in the trading of government securities. A sudden change in reserve money arising from open market operations transactions changes bank reserves proportionately without significantly affecting currency and term and demand deposits, except for the interest component in maturing securities. Accordingly, aggregate money supply is insignificantly affected by the reserve money shock.

[insert Figure 7 here]

Both output and consumer prices respond significantly to unexpected changes in M2. An unanticipated 6.1 percent increase in M2 is followed by a rise in output, which peaks at 2.4 percent above baseline after 10 months and is significant up to 2 years. Consumer prices respond to the monetary expansion with an initial price increase, peaking at 0.6 percent above baseline after 8 months. The response is significant up to five months. 
To determine the importance of the money effect model, Figure 8 presents impulse responses of consumer prices and output to bank rate and reserve money shocks in two scenarios: endogenous and exogenous M2. The figure confirms that M2 contains important additional information in the monetary transmission process, which is more pronounced in the responses of output to bank rate shocks and consumer prices to reserve money shocks.

[insert Figure 8 here]

(c) The Composite Model: Full Sample

Preliminary indications from the preceding section suggest that bank lending, exchange rate and money effect channels contain important additional information for the monetary transmission process in Malawi. Putting everything together, a composite model of monetary transmission in Malawi can be drawn with the following vector of endogenous variables:

$y_{t}^{\prime}=\left[G Y_{t}, C P_{t}, B L_{t}, X R_{t}, M 2_{t}, B R_{t}, R M_{t}\right]$

which is identified according to system of equations (5). Impulse responses for the consolidated model over a five year period are presented in Figure 9. The figure illustrates that the bank lending and money effect channels are important channels of monetary transmission in Malawi but that the transmission process is somewhat weak. Among the three intermediate policy targets, none responds significantly to reserve money shocks. However, bank lending and M2 respond significantly to bank rate shocks, although the M2 response is only marginally significant. Bank lending responds to a sudden 2.2 percent increase in the bank rate with a decline, bottoming at 1.7 percent below baseline after 2 years. The response is significant between 12 and 30 months. M2 responds to the shock with an instantaneous decline of 0.8 percent, before rising in the next 6 months and declining thereafter. The response is marginally significant between 16 and 24 months.

[insert Figure 9 here]

Output responds significantly to unexpected changes in both bank lending and M2. An unanticipated 5.7 percent increase in bank lending causes output to rise, peaking at 1.3 percent above baseline after 15 months. A sudden 5.8 percent increase in M2 also causes output to rise, peaking at 1.6 percent above baseline after 5 months. Consumer prices, however, respond insignificantly to shocks emanating from both bank lending and M2, consistent with the earlier findings.

The money effect channel is confirmed by significant responses of M2 to bank lending and exchange rate shocks. In contrast, the exchange rate channel is not well established. Exchange rates respond insignificantly to all monetary variables in the model but they prompt significant responses in both output and consumer prices. Thus, while there is no evidence that they are driven by monetary policy shocks, exchange rates are an important determinant of output and consumer prices. On this basis, it is probable that exchange rates are exogenously determined in the model. To confirm this claim, the composite model is reestimated with the exchange rate treated as an exogenous variable and similar results are obtained.

\section{(d) The Composite Model: Truncated Sample}

Historical events in Malawi suggest that financial sector operations during the pre-1994 period were considerably different to the post-1994 period. The country had credit ceilings until 1988, direct interest rate controls until May 1990 and a fixed exchange rate peg until February 1994. In the post-1994 period, numerous financial innovations emerged, the number of commercial banks increased considerably (from two in 1993 to 11 in January 2010) and the financial sector became reasonably competitive. Assuming that the impact of financial sector operations on economic activity may have also changed in the post-1994 period, the composite model (with endogenous exchange rates) is re-estimated with the sample period truncated, starting instead from 1994:03. The truncation date is chosen to separate the periods of fixed exchange rate peg (pre-1994:03) and floating exchange rates (post-1994:02). Impulse responses for the model with a 
truncated sample are presented in Figure 10. While the patterns are broadly similar to the full sample patterns, there are notable differences as well.

[insert Figure 10 here]

First, the response of exchange rates to unexpected changes in the bank rate is significant in the truncated sample. This is not surprising since the exchange rate was flexible during the entire post-1994 period, which allowed the Malawian Kwacha to respond freely to monetary variables. The response of output to exchange rate shocks, while still significant, is now less pronounced compared to the full sample. Thus, the impact of exchange rate shocks on policy goals is weaker in the truncated model although the exchange rate as a monetary policy transmission channel is now apparent. Second, the significant response of M2 to bank rate shocks is more pronounced in the truncated sample. This underlines the importance of monetary policy in the flexible exchange rate regime. Third, the significant output response to unexpected changes in bank lending is more pronounced in the truncated model, highlighting the importance of bank lending as a standalone channel of monetary transmission.

To determine the proportion of fluctuations in a given variable caused by different shocks, variance decompositions of each variable in the composite model with a truncated sample are computed at forecast horizons of 1 to 5 years (see Table 2). The table shows that, besides own shocks, output fluctuations are largely attributed to M2 up to about a year, exchange rates at about 2 years and bank lending from about 3 years and beyond. Collectively, bank lending, exchange rates and M2 account for 8.12 percent of the fluctuations in output after a year, 19.4 percent after 2 years, 28 percent after three years and 36.9 percent after 5 years.

[insert Table 2 here]

Excluding own shocks, variations in consumer prices are mostly accounted for by exchange rates up to about 3 years and by bank lending thereafter. M2 accounts for less than 1 percent of the fluctuations in consumer prices across the forecast horizon, implying that shocks in aggregate money supply are not responsible for inflation in Malawi. Consistent with earlier findings, consumer prices account for a larger proportion of the fluctuations in both bank rate and reserve money fluctuations, given the two policy goals, reconfirming that the primary goal of monetary policy in Malawi is price stability, though the output goal is also pursued.

\section{(e) Robustness Check}

While all models are subjected to robustness checks, only results of the estimated composite model from the truncated sample are reported. Structural estimates of the coefficients in matrices $A$ and $B$ of the model show that 12 of the 17 structural coefficients have expected signs. In addition, nearly all coefficients in the model have standard errors with values of less than one, implying that they are efficient and hence form a solid basis for measuring monetary policy shocks. Inverse roots of the characteristic AR polynomial for the determination of stability (stationarity) of the model show that all inverse roots of the characteristic AR polynomial have modulus less than one and they lie inside the unit circle, indicating that at the chosen lag length (of order three), the estimated model is stationary or stable. Finally, serial correlation test results show no evidence of serious serial correlation in the model. Gujarati (2003) points out that as a rule of thumb, if the pairwise or zero order correlation coefficient between two regressors is in excess of 0.8 , then multicollinearity is a problem. Thus, the composite model with a truncated sample is robust and its inferences can be relied upon.

While the debate concerning whether or not to transform models to stationary form by difference or cointegration operators when dealing with I(1) variables appears to lean towards the Sims et al. (1990) conclusion, some authors maintain support for the traditional approach of transforming the data to stationary 
regressors prior to estimation regardless of whether the point of focus is long run or short run relationships (see, for example Enders, 2004). To illustrate that results obtained from the two methodologies are not diametrically opposed to each other, the study also estimates the composite model using a cointegrated SVAR, which demonstrates that while there may be some differences, as expected, the estimation results are on the whole similar to what is obtained from estimation in levels. Understandably, a number of differences also show up. Among the differences, impulse responses from the cointegrated SVAR die off very quickly compared to those from the estimation in levels. In order to retain clear visual images, the forecast horizon is reduced from 60 months in the levels estimation to 12-month in the cointegrated SVAR.

The cointegrated SVAR confirms the finding in the levels estimation that monetary policy in Malawi employs hybrid operating procedures, with the bank rate and reserve money as operating tools. Both the bank rate and reserve money respond significantly to shocks in the three intermediate targets of monetary policy namely exchange rates, aggregate money supply and bank lending, revealing that the central bank is concerned with movements in the three targets and to achieve desired levels in these targets, the two policy tools are used. Consistent with the levels estimation, the cointegrated SVAR also shows that the exchange rate and money effect are important channels of monetary transmission in the country, though the impact is not as pronounced as in the levels estimation. The effect of bank lending in the monetary transmission process, however, is insignificant in the cointegrated SVAR.

The observed differences from the two estimation approaches are not unexpected. An important source of these differences is the imposition of what may be possibly incorrect cointegrating restrictions in the process of estimating the cointegrated VAR. Kim and Roubini (2000) and Becklelmans (2005) argue that this is usually the case in cointegrated VARs with the implication that the resulting inferences are often incorrect as well. In an attempt to circumvent the problem, some studies opt for a simple differences specification (see, for example, Weitong, 2007; Boivin \& Giannoni, 2002; Kasa \& Popper, 1997; Kugler et al, 2004; Karame \& Olmedo, 2002; Mihira \& Sugihara, 2000). The approach, however, is not persuasive as it yields inconsistent estimates if some variables are cointegrated (Bernanke \& Mihov, 1997).

\subsection{SUMMARY AND CONCLUSIONS}

This paper set out to investigate the process through which monetary policy affects consumer prices and output in Malawi. Using innovation accounting in a structural vector autoregressive model, it is established that contrary to the official position that monetary policy in the country targets reserve money only, monetary authorities in Malawi also target short term interest rates. Effectively, the country employs hybrid operating procedures and it is demonstrated that the bank rate is a more effective measure of monetary policy than reserve money. In line with Part III, Section 4(d) of the RBM Act of 1989, it is also established that monetary authorities in the country pursue both price stability and high growth and employment objectives. It is further shown that price stability is the principal objective of monetary policy in the country. With the exception of exchange rate shocks, however, consumer prices respond weakly to monetary impulses suggesting that inflation in Malawi may not be dominated by monetary factors. The fact that food costs have a preponderant weight (58.1 percent) in the all items national composite consumer price index reveals that structural rigidities in food production may be more important determinants of inflation than monetary considerations.

The study also illustrates that bank lending, exchange rates and aggregate money supply contain important additional information on the transmission process of monetary policy shocks in Malawi. Besides own shocks, output fluctuations are largely attributed to M2 up to about a year, exchange rates at about 2 years and bank lending from about 3 years and beyond. Excluding own shocks, variations in consumer prices are mostly accounted for by exchange rates up to about 3 years and bank lending thereafter. M2 accounts for less than 1 percent of the consumer price fluctuations across the five-year forecast horizon.

Truncating the study period to include only the flexible exchange rate period (post-1994) reveals two interesting issues. First, the role of the exchange rate becomes more conspicuous although its impact on 
economic activity is weakened. Second, the importance of aggregate money supply and bank lending in transmitting monetary policy impulses is enhanced. It is concluded, therefore, that with the floatation of the Malawian Kwacha in 1994, the monetary transmission process evolved from a weak, blurred process to a somewhat strong, less ambiguous mechanism, consistent with theoretical expectations.

\section{REFERENCES}

BANDA, W. (2004). Exchange Rate Management Under Monetary Targeting. Paper Presented at the Dealers Association of Malawi Lakeshore Conference, November 27-28, 2004 pp. 1.21.

BECKLEMANS, L. (2005). Credit and Monetary Policy: An Australian SVAR. Reserve Bank of Australia Research Discussion Paper Series, 2005-06 (September): 1.29.

BERNANKE, B. (1986). Alternative Explanations of the Money-Income Correlation. NBER Working Paper Series, WP No. 1842: 1.62.

BERNANKE, B. AND GERTLER, M. (1995). Inside the Black Box: The Credit Channel of Monetary Policy Transmission. Journal of Economic Perspectives, 9(4): 27.48.

BERNANKE, B. AND MIHOV, I. (1997). What Does the Bundesbank Target. European Economic Review, 41(6): 1025.1053.

BERNANKE, B. AND MIHOV, I. (1998). Measuring Monetary Policy. The Quarterly Journal of Economics, 113(3): 869.902.

BLUNDELL-WIGNALL, A. AND GIZYCKI, M. (1992). Credit Supply and Demand and the Australian Economy. Reserve Bank of Australia Discussion Paper Series, DP No. 9208: 1.48.

BOLNICK, B. (1991). Weak Links in the Monetary Transmission Mechanism: The Case of Malawi. ODI/HIID Conference on Improving Monetary Policy in Africa and Asia, pp. 1-27.

BORYS, M. AND HOVARTH, R. (2007). The Effects of Monetary Policy in the Czech Republic: An Empirical Study. CERGE-EI Working Paper Series, WP No. 339: pp. 1-26.

BRISCHETTO, A. AND VOSS, G. (1999). A Structural Vector Autoregression Model of Monetary Policy in Australia. Reserve Bank of Australia Discussion Paper Series, DP No. 1999-11.

CHENG, K. (2006). A VAR Analysis of Kenya's Monetary Policy Transmission Mechanism: How Does the Central Bank's Repo Rate Affect the Economy? IMF Working Paper Series, WP/06/300: 1.26.

CHRISTIANO, L., EICHENBAUM, M. AND EVANS, C. (1998). Monetary Policy Shocks: What Have we Learned and to What End? NBER Working Paper Series, WP No. 6400: 1.77.

CLARIDA, R. AND GERTLER, M. (1996). How the Bundesbank Conducts Monetary Policy. NBER Working Paper Series, WP No. 5581: 1.50.

DABLA-NORRIS, E. AND FLOERKEMEIER, H. (2006). Transmission Mechanisms of Monetary Policy in Armenia: Evidence From VAR Analysis. IMF Working Paper Series, WP/06/248: 1.26.

DISYATAT, P. AND VONGSINSIRIKUL, P. (2003). Monetary Policy and the Transmission Mechanism in Thailand. Journal of Asian Economics, 14: 389.418.

DUNGEY, M. AND PAGAN, A. (2000). A Structural VAR Model of the Australian Economy. Economic Record, 76(235): pp. 321-342.

ENDERS, W. (2004). Applied Econometric Time Series. Hoboken: John Wiley \& Sons, Inc. 2nd Ed.

FAVERO, C. (2001). Applied Macroeconometrics. New York: Oxford University Press Inc.

FRIEDMAN, M. (1962). The Interpolation of Time Series by Related Series. Journal of the American Statistical Association, 57(300): 729.757.

GONDWE, S. (2001). The Impact of Liberalisation Policies on Commercial Bank Behaviour and Financial Savings in Malawi. Unpublished MA Thesis (University of Malawi).

GOVERNMENT OF MALAWI (1989). Reserve Bank of Malawi Act. Laws of Malawi 44(02): pp. 1-19.

GUJARATI, D. (2003). Basic Econometrics. McGraw-Hill 4th Edition.

IRELAND, P. (2005). 'The Monetary Transmission Mechanism.' Boston College Department of Economics Working Paper Series WP No. 168: pp. 1-13.

KAMIN, S., TURNER, P. AND VAN’T DACK, J. (1998). The Transmission of Monetary Policy. BIS Policy papers 3. 
KARAME, F. AND OLMEDO, A. (2002). The Asymmetric Effects of Monetary Policy Shocks: A Nonlinear Structural VAR Approach. Unpublished Manuscript, pp. 1-28.

KIM, S. (1999). Do Monetary Policy Shocks Matter in the G-7 Countries? Using Common Identifying Assumptions About Monetary Policy Across Countries. Journal of International Economics, 48(2): pp. 387-412.

KIM, S. AND ROUBINI, N. (2000). Exchange Rate Anomalies in the Industrial Countries: A Solution with a Structural VAR Approach. Journal of Monetary Economics, 45(3): pp. 561-586.

KUGLER, P., JORDAN, T., LENZ, C. AND SAVIOS, M. (2004). The Analysis of Forward Looking Monetary Policy in a SV AR Framework. Unpublished Manuscript pp. 1-8.

LEEPER, E., SIMS, C. AND ZHA, T. (1996). What Does Monetary Policy Do? Brookings papers on Economic Activity, 2: pp. 1-78.

MATURU, B. (2007). Channels of Monetary Policy Transmission in Kenya. Unpublished Manuscript pp. pp. 1 25.

MELTZER, A. (1995). Money, Credit and (Other) Transmission Processes: A Monetarist Perspective. The Journal of Economic Perspectives, 19(4): pp. 49-72.

MIHIRA, T. AND SUGIHARA, S. (2000). A Structural VAR Analysis of the Monetary Policy in Japan. Economic Research Institute Discussion Paper Series, DP No. 94: pp. 1-28.

MISHKIN, F. (1995). Symposium on the Monetary Transmission Mechanism. Journal of Economic Perspectives, 9(4): pp. 3-10.

MONTIEL, P. (1991). The Transmission Mechanism of Monetary Policy in Developing Countries. IMF Staff Papers, 38(1): pp. 22-57.

MORSINK, J. AND BAYOUMI, T. (2001). A Peek Inside the Black Box: The Monetary Transmission Mechanism in Japan. IMF Staff Papers, 48(1): pp. 22-57.

MUTOTI, N. (2006). Monetary Policy Transmission in Zambia. Bank of Zambia Working Paper Series, WP/06/2006: pp. 1-22.

OBSTEFIELD, M. AND GERTLER, M. (1995). The Mirage of Fixed Exchange Rates. Journal of Economic Perspectives, 9(4): pp. 73-96.

PHIRI, G. (2002). The Monetary Transmission Mechanism in Malawi. Reserve Bank of Malawi Working Paper Series.

PIFFANELLI, S. (2001). The Instrument of Monetary Policy and Germany: A Structural VAR Approach. United Nations Department of Economic and Social Affairs (DESA) Working Paper Series, DP No. 19: pp. 1-6.

RAMASWAMY, R. AND SLOEK, T. (1998). The Real Effects of Monetary Policy in the European Union. IMF Staff Papers, 45: pp. 374-395.

RESERVE BANK OF MALAWI (2007). Balance of Payments and National Accounts, Reserve Bank of Malawi Financial and Economic Review, 39(2): pp 1-75.

SIMS, C. (1980). Macroeconomics and Reality. Econometrica 48: pp. 1-49.

SIMS, C. (1986). Are Forecasting Models Usable for Policy Analysis? Federal Reserve Bank of Minneapolis Quarterly Review, 10(1): pp. 2-16.

SIMS, C. (1992). Interpreting the Macroeconomic Time Series Facts: The Effects of Monetary Policy. European Economic Review, 36: pp. 975-1011.

SIMS, C., STOCK, J. AND WATSON, M. (1990). Inference in Linear Time Series Models with Some Unit Roots. Econometrica, 58(1): PP. 113-144.

SIMS, C. AND ZHA, T. (2006). Does monetary policy generate recessions? Macroeconomic Dynamics 10(2): PP. 231-272.

STOCK, J. AND WATSON, M. (2001). Vector Autoregressions. Unpublished Manuscript pp. 1-28.

TAYLOR, J. (1995). The Monetary Transmission Mechanism: An Empirical Framework. Journal of Economic Perspectives, 9(4): pp. 11-26.

VONNAK, B. (2005). Estimating the Effects of Hungarian Monetary Policy Within a Structural VAR Framework. Magyar Nemzeti Bank Working Paper Series, WP no. 2005/1: pp. 1-37.

WEITONG, R. (2007). Economic Fluctuations and Japanese Monetary Policy: Two Empirical Studies with SVAR Approach. Unpublished Manuscript pp. 1-64. 

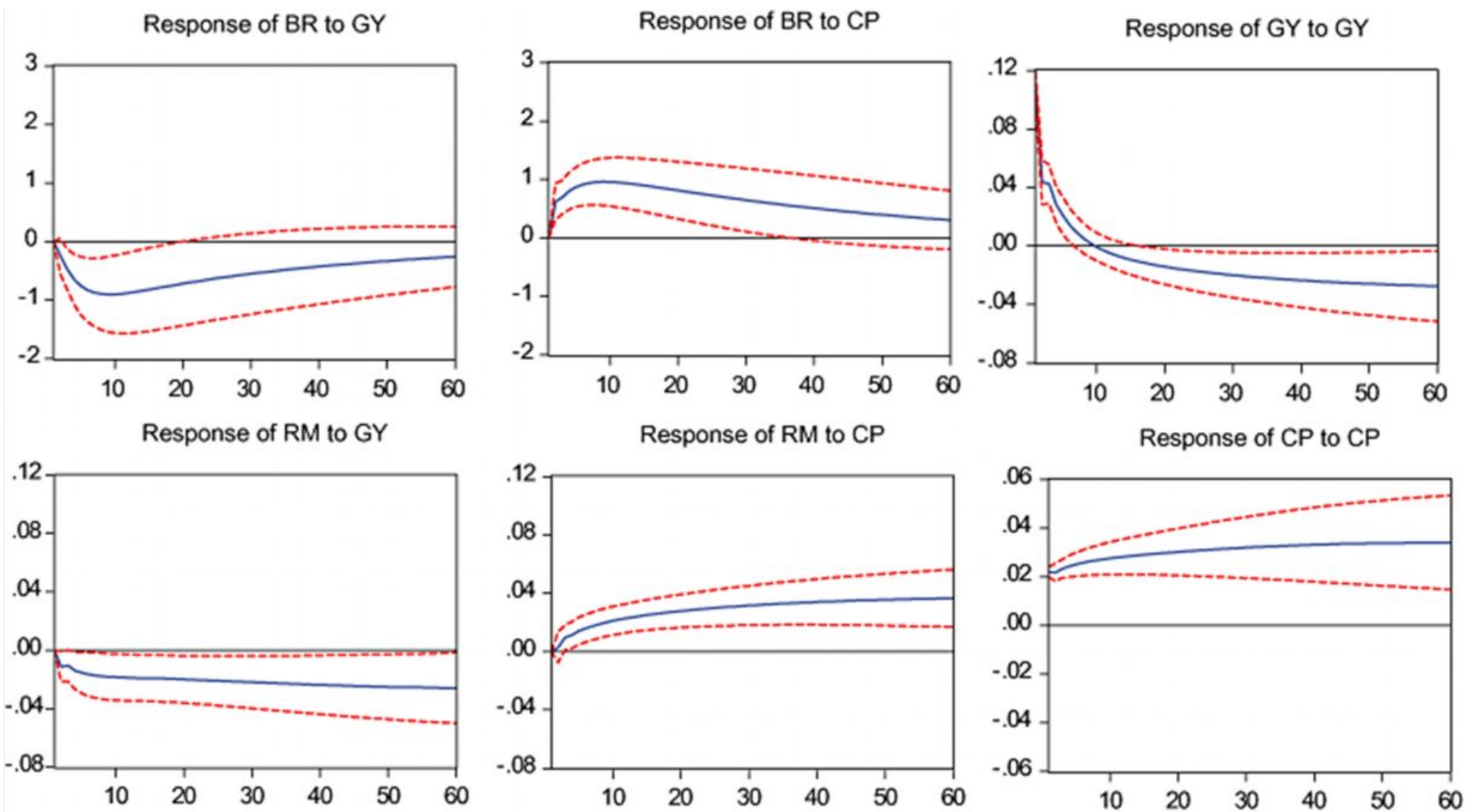

Figure 1. Impulse responses of bank rate and reserve money: The generic model 

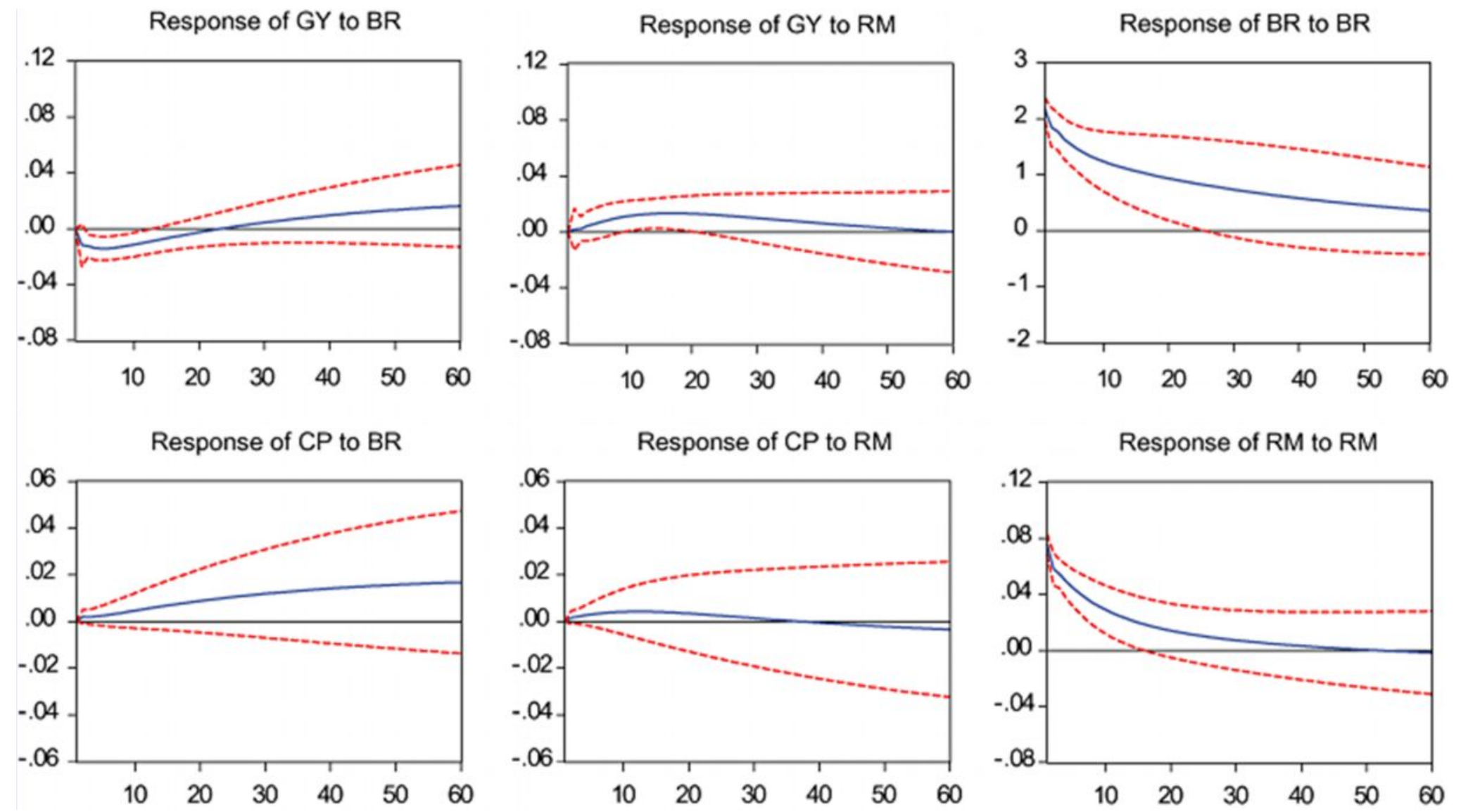

Figure 2. Impulse responses of output and consumer prices: The generic model 


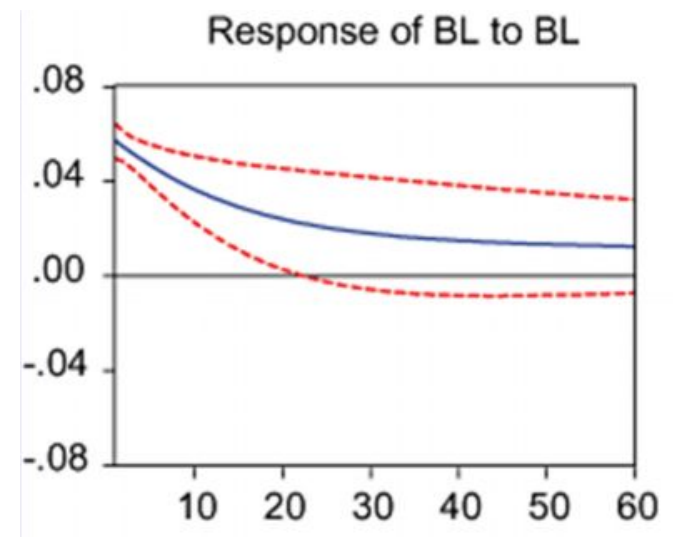

Response of GY to BL

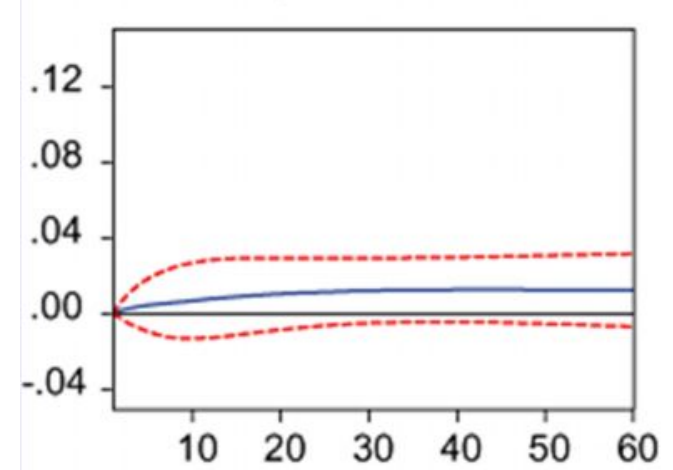

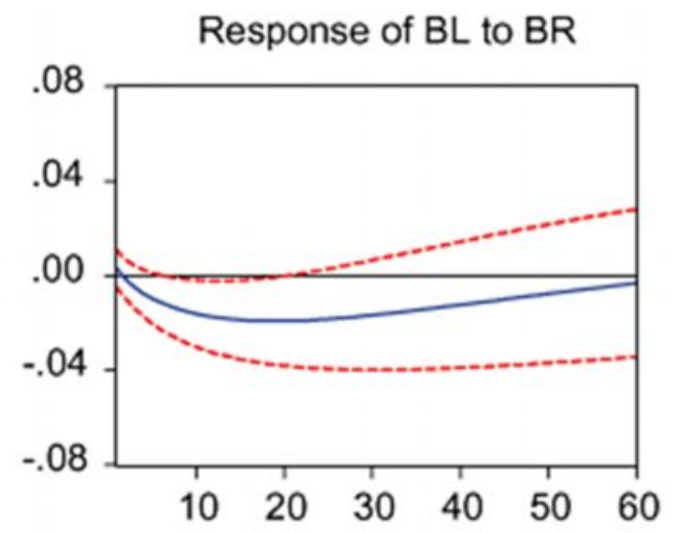

Response of $\mathrm{CP}$ to $\mathrm{BL}$

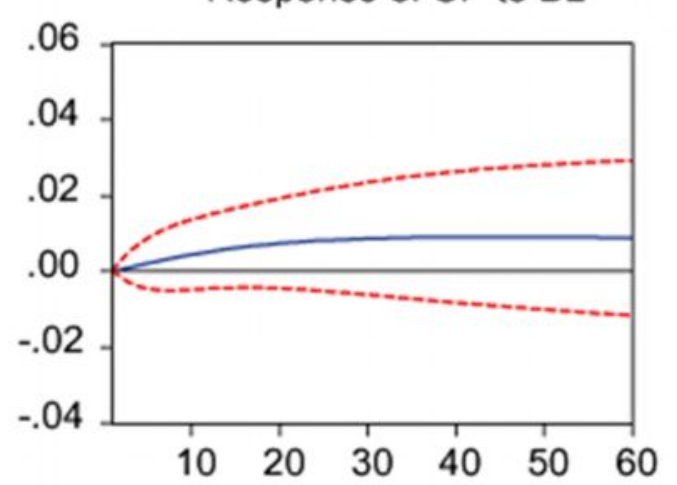

Response of BL to RM

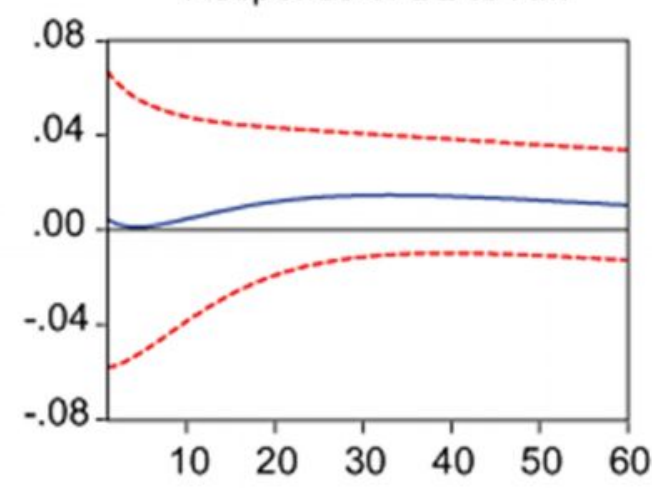

Response of $\mathrm{BL}$ to $\mathrm{CP}$

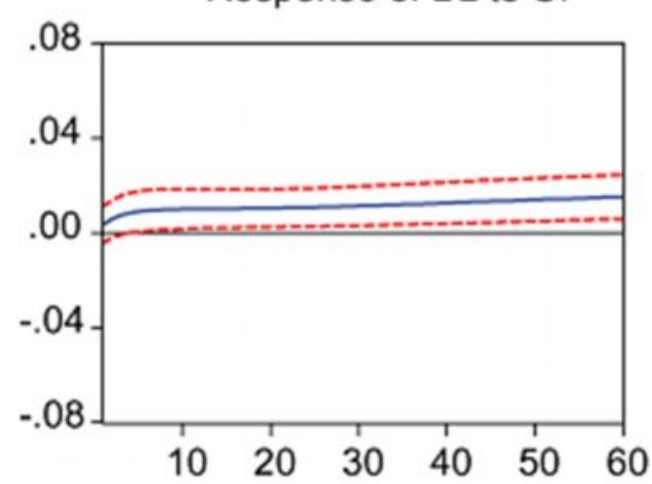



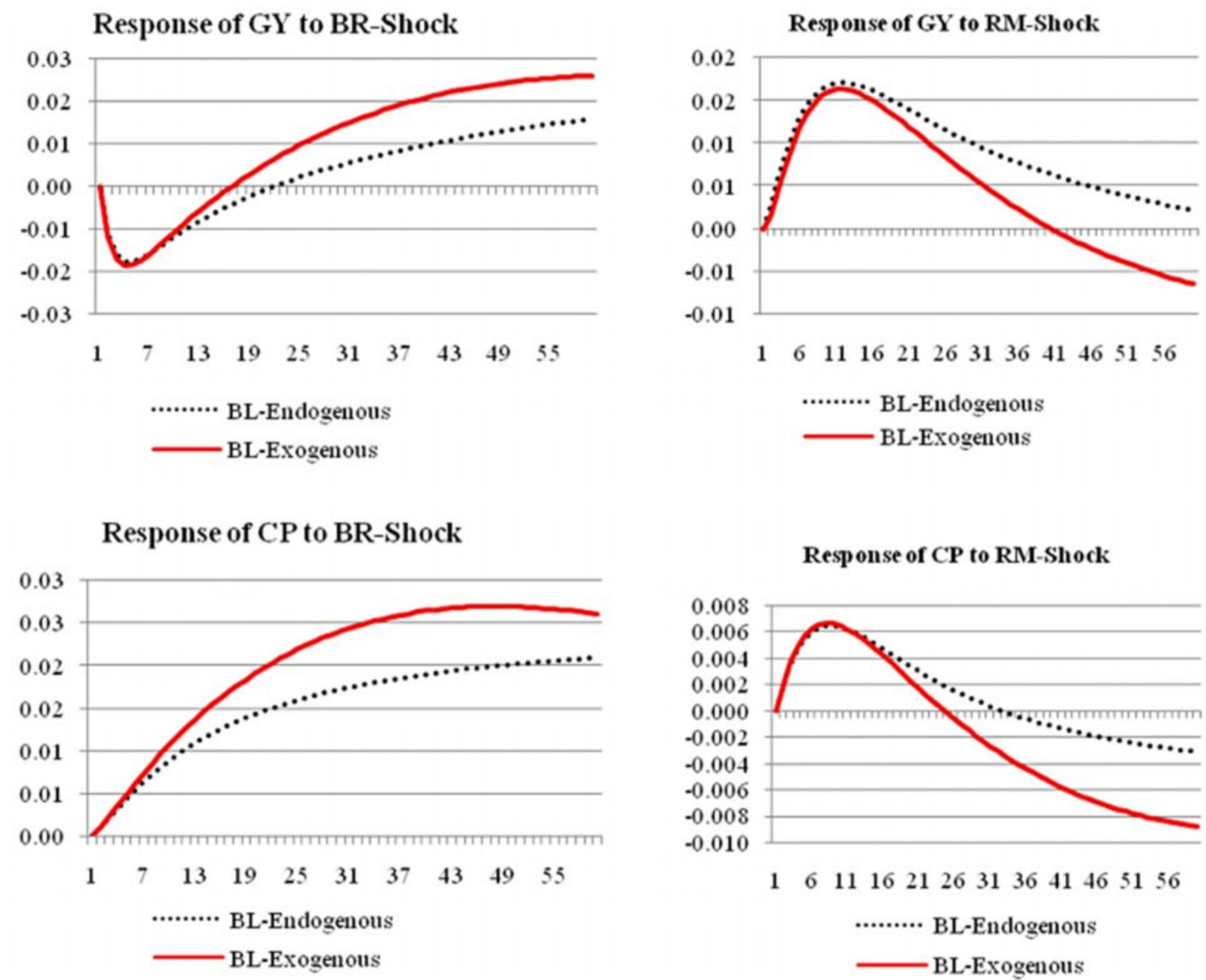

Figure 4. Impulse responses of output and consumer prices to bank rate and reserve money shocks with endogenous and exogenous bank lending 

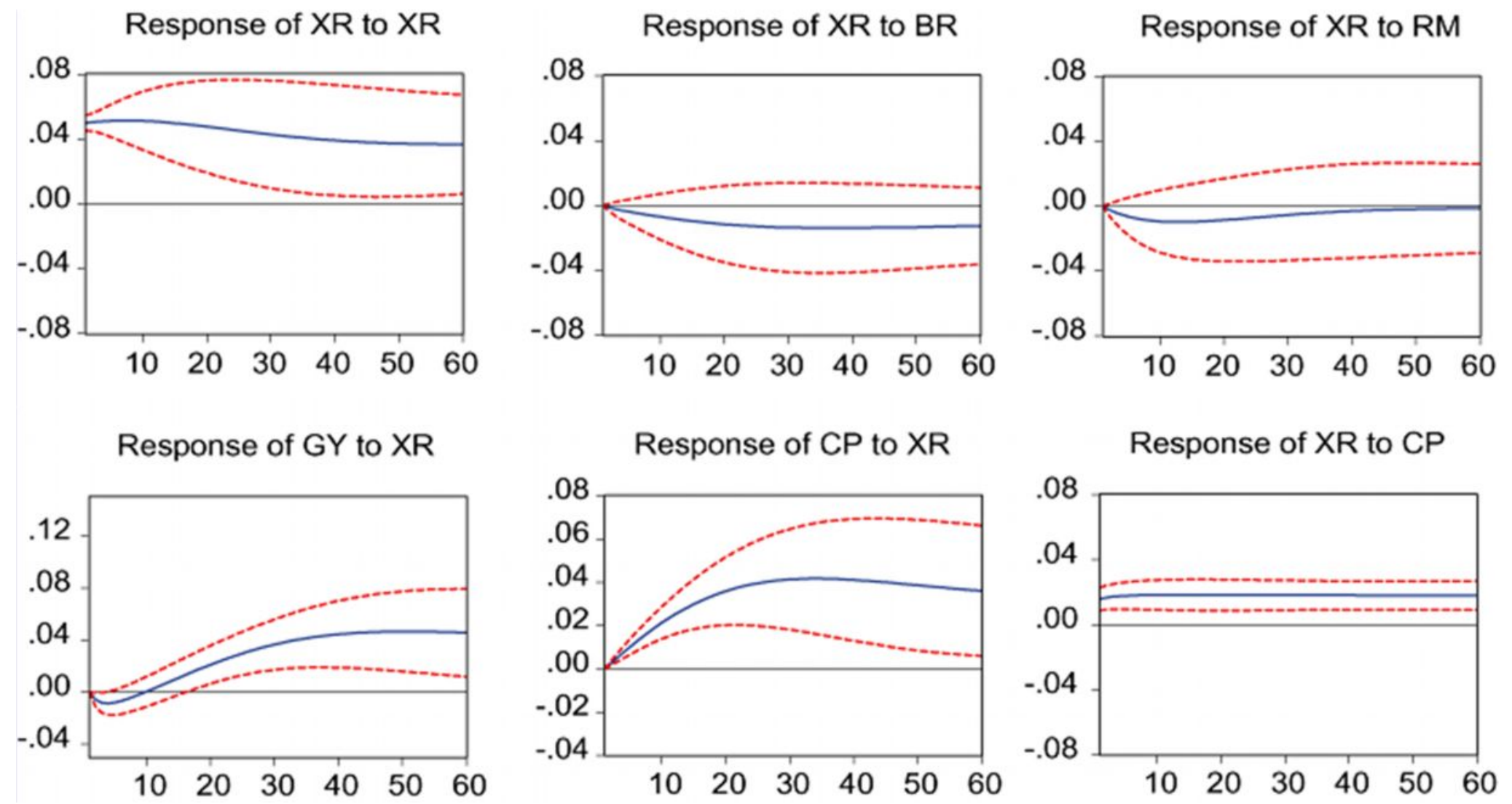

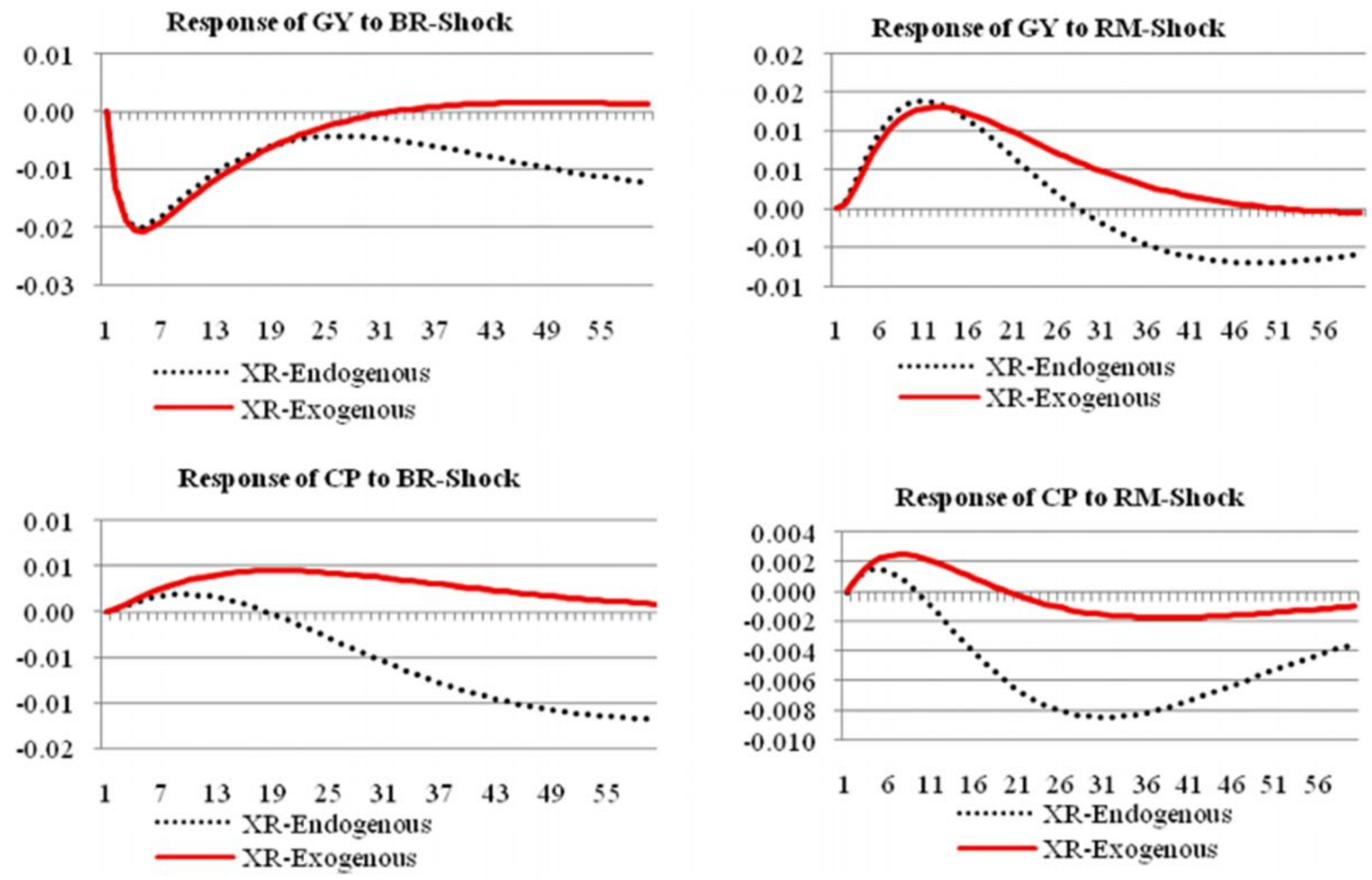

Figure 6. Impulse Responses of output and consumer prices to bank rate and reserve money shocks with endogenous and exogenous exchange rates 

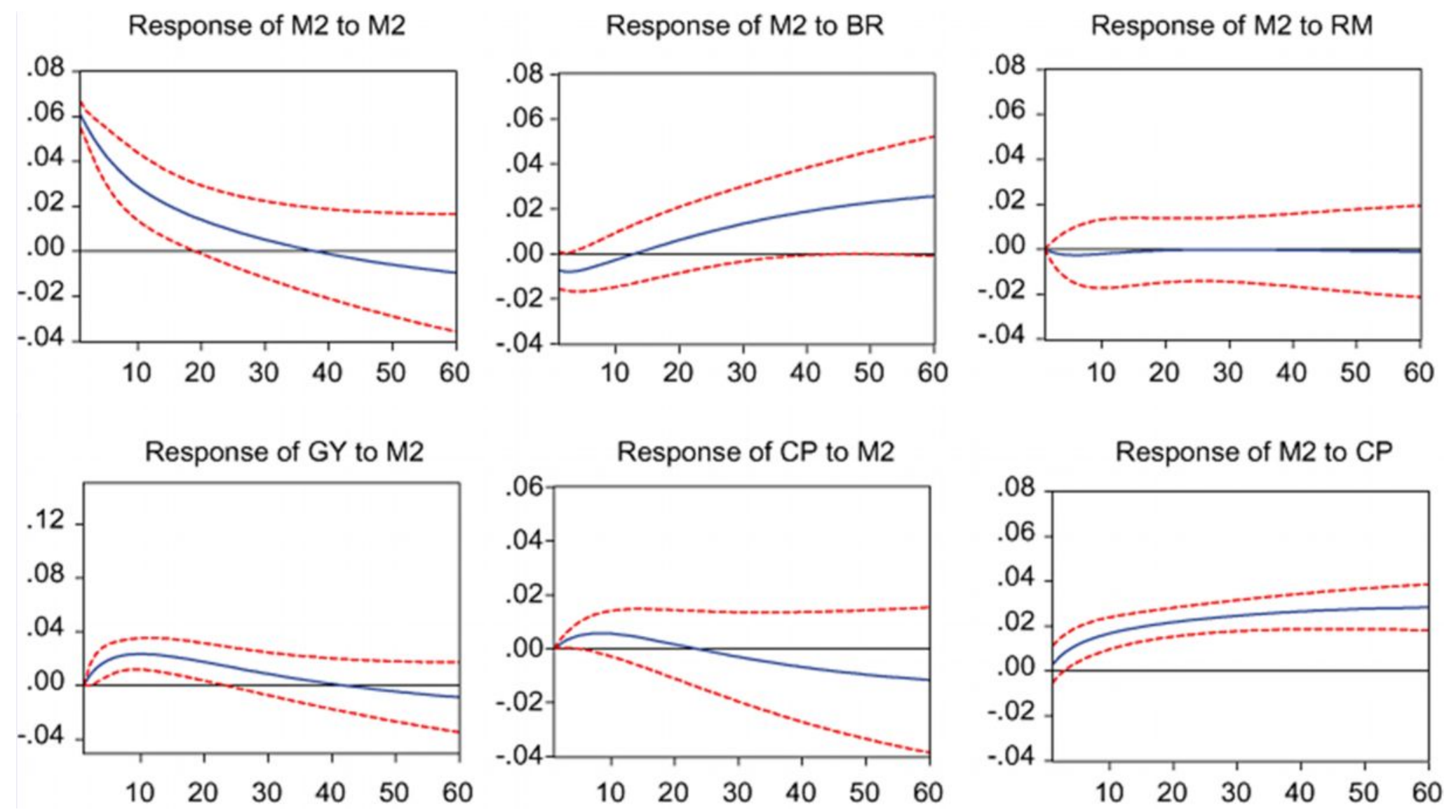

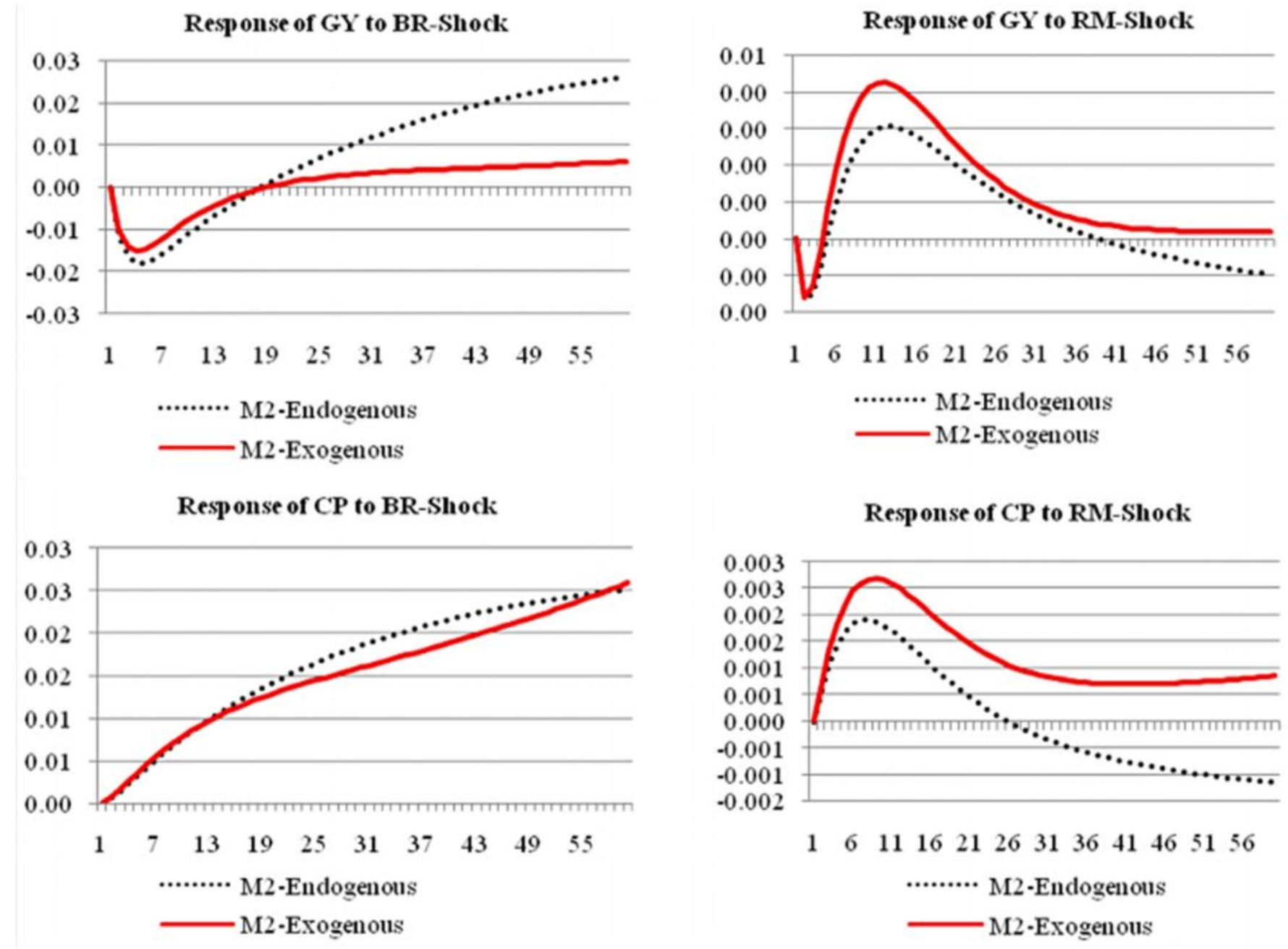

Figure 8. Impulse Responses of output and consumer prices to bank rate and reserve money shocks with endogenous and exogenous M2 


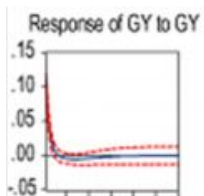

102030405060

Resporse $d C P$ to $G Y$

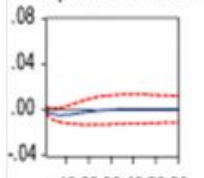

102030405060

Response of BL $10 \mathrm{GY}$

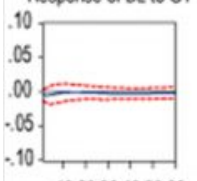

102030405060

Response of XR to GY

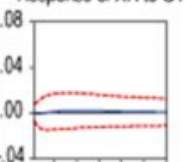

102030405060

Response o I I.2 10 GY

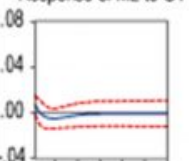

102030405060

Response of BR to GY

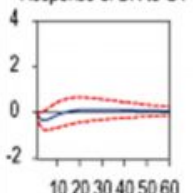

102030405060

Response of RMI to GY

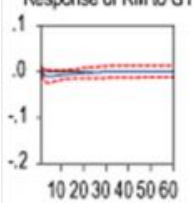

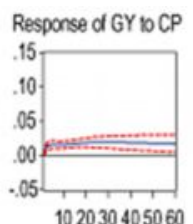

102030405060

Response of CP to CP

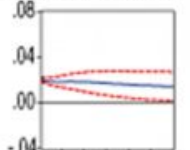

102030405060
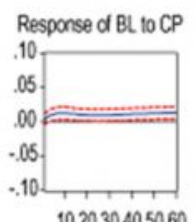

102030405060
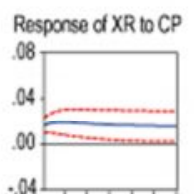

102030405060

Response of MI: $10 \mathrm{CP}$

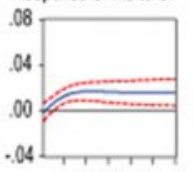

102030405060

Response of BR to CP

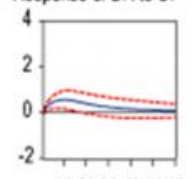

102030405060

Response of $R M A$ to $C P$

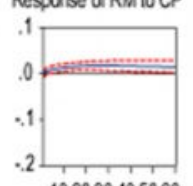

102030405060

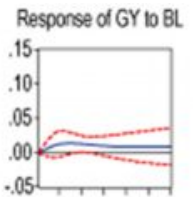

102030405060

Response of CP to BL

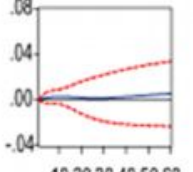

102030405060

Response of BL $10 \mathrm{BL}$

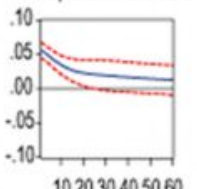

102030405060

Response of XR to BL

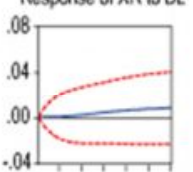

102030405060

Response of $M 210 \mathrm{BL}$

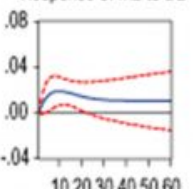

102030405060

Response of BR to BL

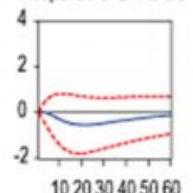

102030405060
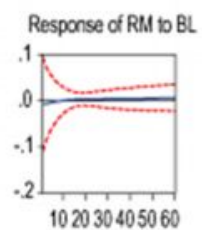

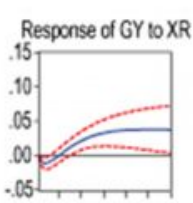

102030405060

Response of CP to XR

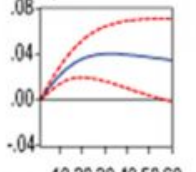

102030405060

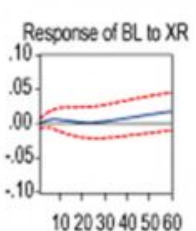

102030405060

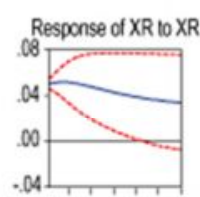

102030405060
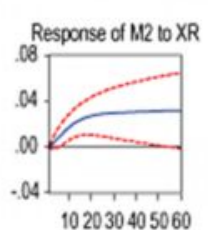

102030405060
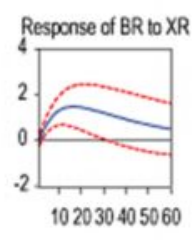

Response of RM to XR

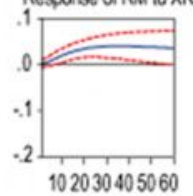

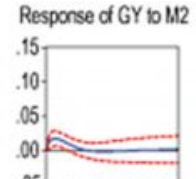

$.05,1,1,1$

102030405060
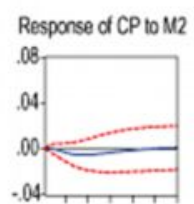

$.04,1,1,1$

Response of BL to M2

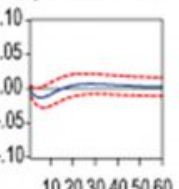

102030405060

Response of XR to M2

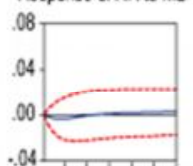

102030405060

Response of I.:2 to M2

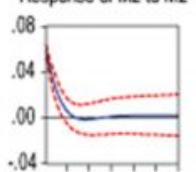

102030405060

Response of BR to M12

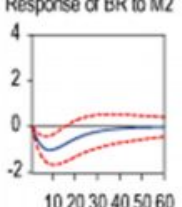

102030405060

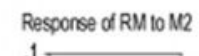

\begin{tabular}{l}
\hline 1.1 \\
.21 \\
102030405060
\end{tabular}
Response of GY 10 BR

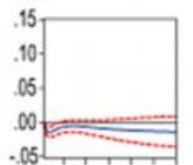

102030405060
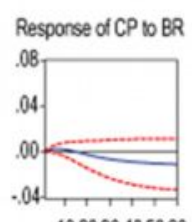

102030405060

Response of $B$. 10 BR

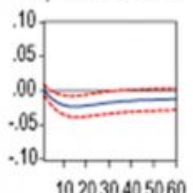

102030405060

Response of XR to BR

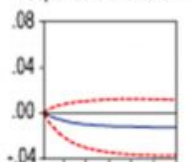

102030405060

Response of M2 10 BR

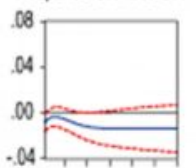

102030405060

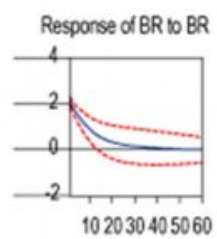

102030405060
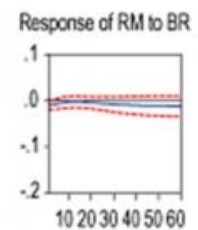

102030405060
Response of GY to RM

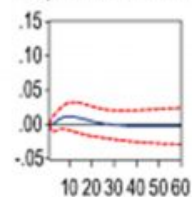

102030405060

Response of (PP to RM

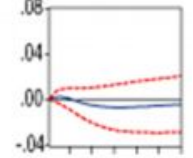

102030405060

Response of BL to RM

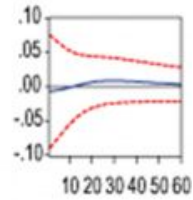

102030405060

Response of XR to RM

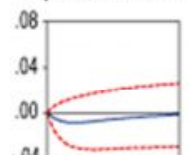

102030405060

Response of M12 to RM

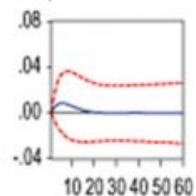

102030405060
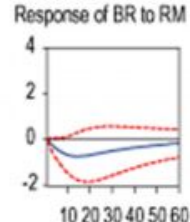

102030405060

Response of RM 10 RM

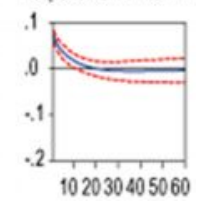

Figure 9. Impulse responses for the composite model (full sample) with endogenous exchange rates 

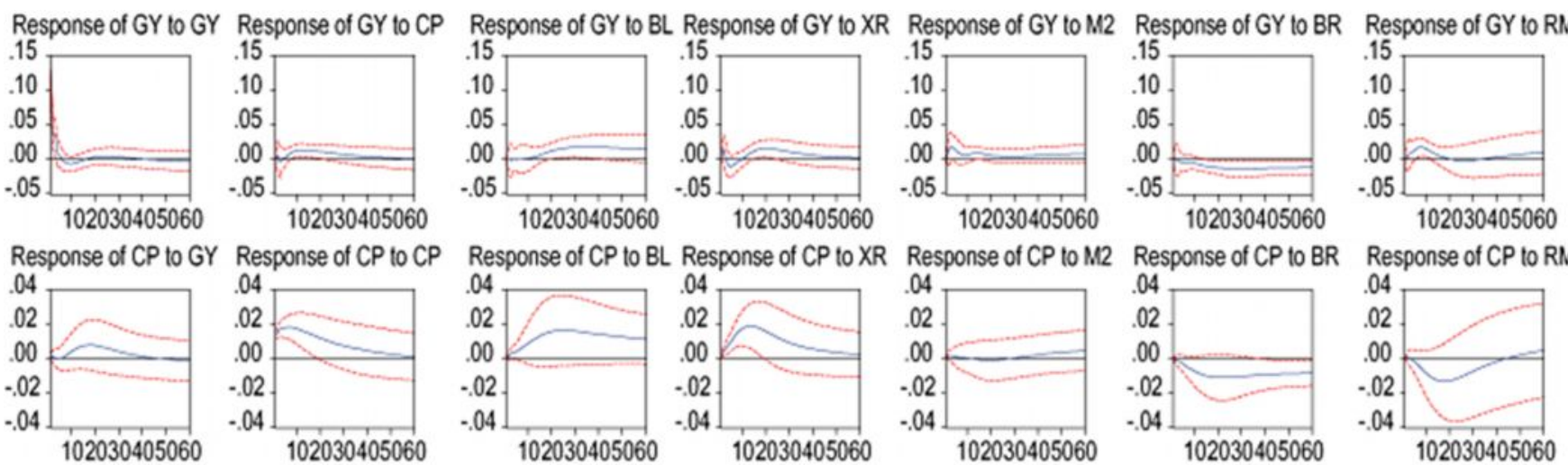

Response of BL to GY Response of $B L$ to $C P$
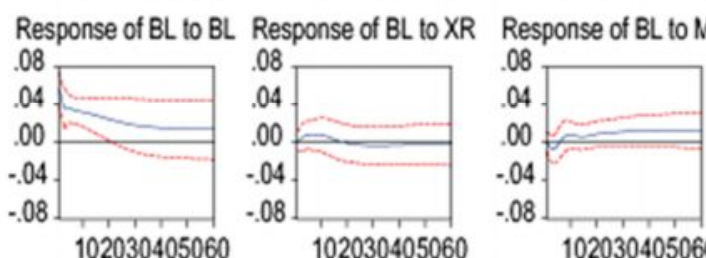

Response of $\mathrm{BL}$ to $\mathrm{BR}$
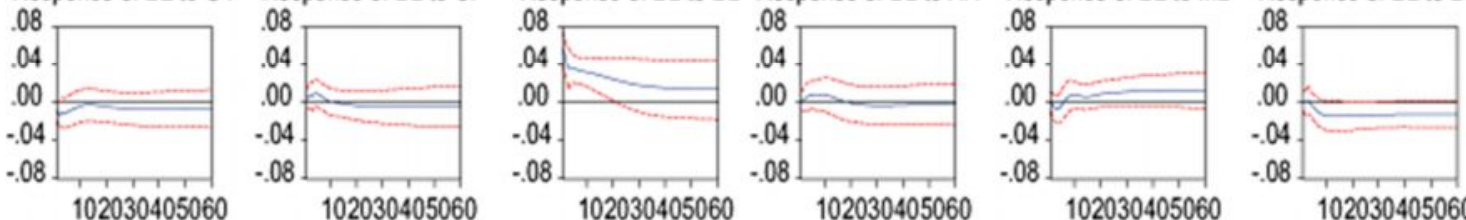

$102030405060 \quad 102030405060$

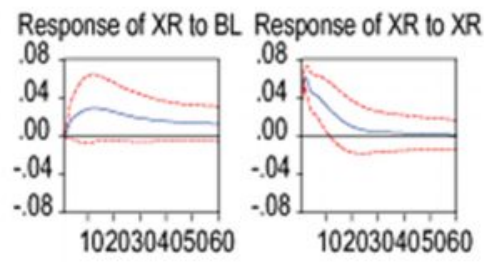

102030405060

102030405060

Response of BL to RM
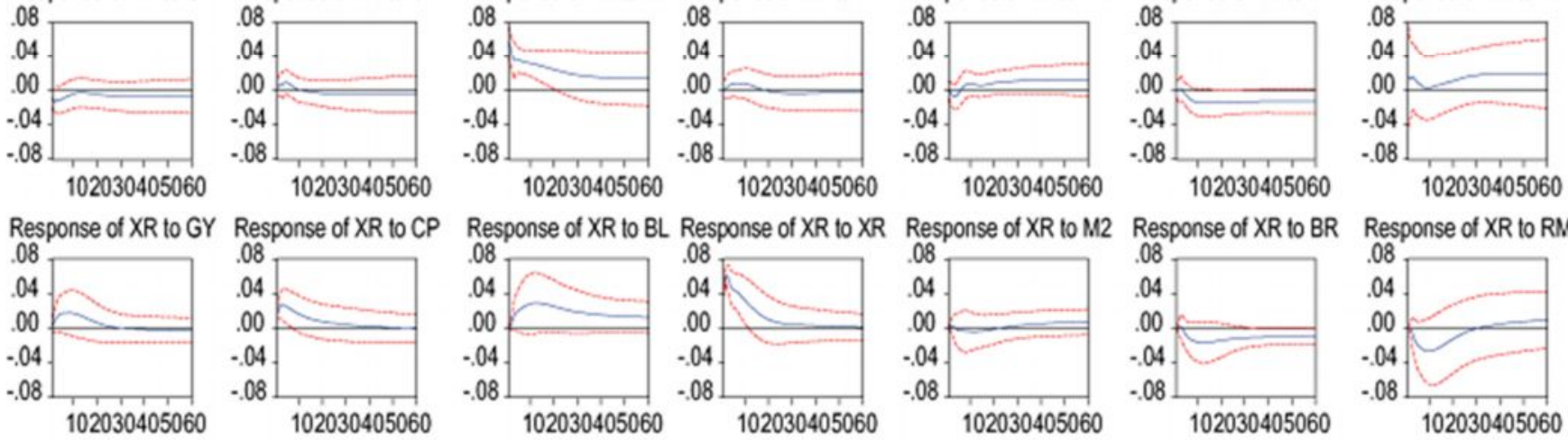

102030405060

Response of M2 to GY Response of M2 to CP
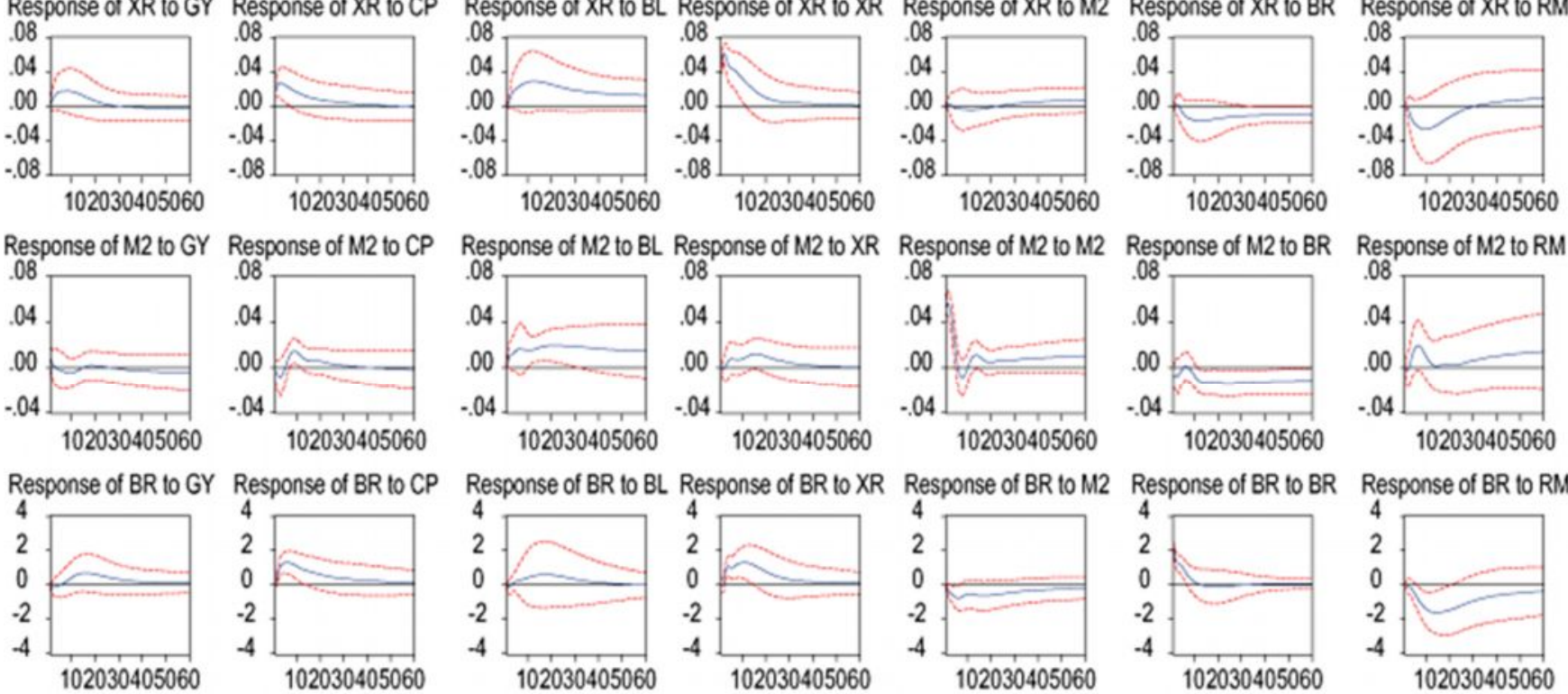

Response of M2 to RM

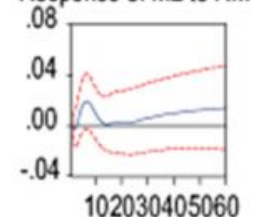

Response of RM to GY Response of RM to $\mathrm{CP}$

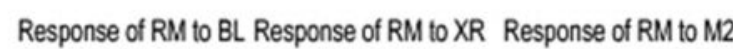

Response of $\mathrm{RM}$
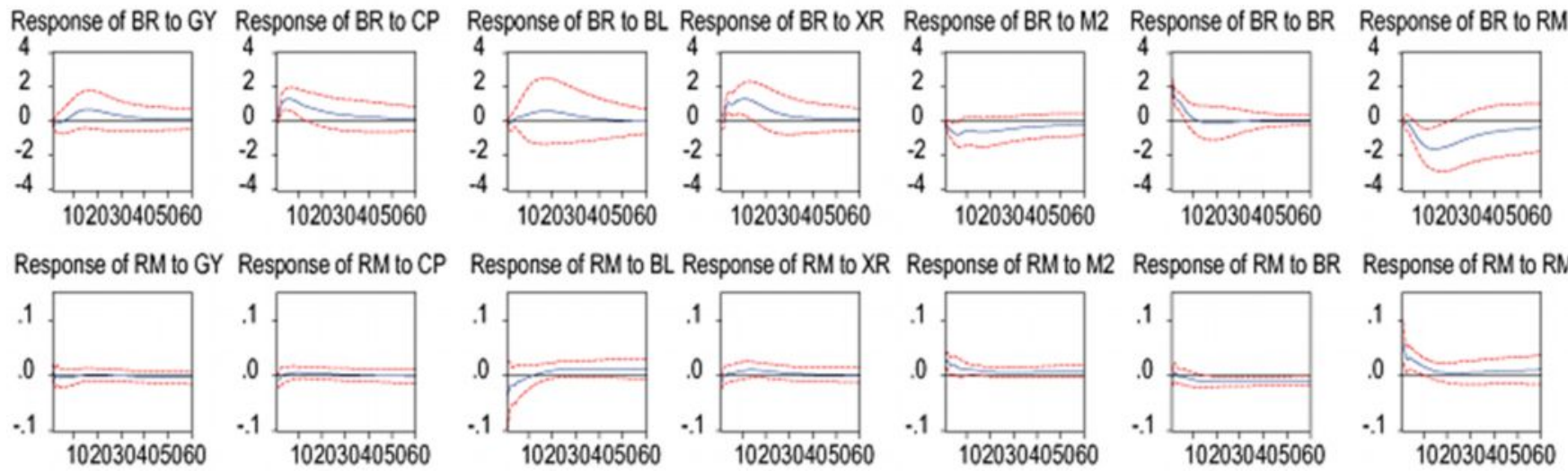

Figure 10. Impulse responses for the composite model with a truncated sample 
Table 1. Variance decomposition for the generic model

\begin{tabular}{|c|c|c|c|c|c|}
\hline \multicolumn{6}{|c|}{ Variance decomposition of $G Y$} \\
\hline Month & Standard error & $G Y$ & $C P$ & $B R$ & $R M$ \\
\hline $\begin{array}{r}1 \\
6 \\
12 \\
24 \\
36 \\
48 \\
60\end{array}$ & $\begin{array}{l}0.108091 \\
0.134969 \\
0.148561 \\
0.185650 \\
0.230012 \\
0.277516 \\
0.325403\end{array}$ & $\begin{array}{l}100 \\
92.3109 \\
76.8961 \\
55.1723 \\
45.2397 \\
40.2602 \\
37.3931\end{array}$ & $\begin{array}{l}0 \\
2.26977 \\
11.7495 \\
30.9392 \\
42.9679 \\
49.4123 \\
52.581\end{array}$ & $\begin{array}{l}0 \\
4.85201 \\
7.83193 \\
5.84306 \\
4.38645 \\
4.79446 \\
5.96782\end{array}$ & $\begin{array}{l}0 \\
0.56728 \\
3.52248 \\
8.04545 \\
7.40598 \\
5.53305 \\
4.0581\end{array}$ \\
\hline \multicolumn{6}{|c|}{ Variance decomposition of $C P$} \\
\hline $\begin{array}{l}\text { Month } \\
1 \\
6 \\
12 \\
24 \\
36 \\
48 \\
60\end{array}$ & $\begin{array}{l}\text { Standard error } \\
0.021924 \\
0.061469 \\
0.099171 \\
0.161362 \\
0.214541 \\
0.261969 \\
0.304650\end{array}$ & $\begin{array}{l}G Y \\
0.00429 \\
8.83843 \\
17.2802 \\
23.9426 \\
26.3566 \\
27.408 \\
27.9006\end{array}$ & $\begin{array}{l}C P \\
99.9957 \\
89.5588 \\
79.9114 \\
71.2309 \\
67.0872 \\
64.4648 \\
62.5823\end{array}$ & $\begin{array}{l}B R \\
0 \\
0.70214 \\
1.4836 \\
3.73211 \\
5.87991 \\
7.65085 \\
9.06388\end{array}$ & $\begin{array}{l}\boldsymbol{R} M \\
0 \\
0.90065 \\
1.32472 \\
1.09445 \\
0.67633 \\
0.47635 \\
0.45322\end{array}$ \\
\hline \multicolumn{6}{|c|}{ Variance decomposition of $B R$} \\
\hline $\begin{array}{l}\text { Month } \\
1 \\
6 \\
12 \\
24 \\
36 \\
48 \\
60\end{array}$ & $\begin{array}{c}\text { Standard error } \\
2.163468 \\
4.897248 \\
6.776396 \\
8.828680 \\
9.836133 \\
10.36665 \\
10.65306\end{array}$ & $\begin{array}{l}G Y \\
0 \\
8.22009 \\
14.6781 \\
17.4205 \\
17.7836 \\
17.8461 \\
17.8509\end{array}$ & $\begin{array}{l}C P \\
0 \\
13.0522 \\
18.6407 \\
21.865 \\
22.7513 \\
23.0723 \\
23.1937\end{array}$ & $\begin{array}{l}B R \\
100 \\
76.6691 \\
60.9944 \\
50.6677 \\
47.3985 \\
46.0195 \\
45.3665\end{array}$ & $\begin{array}{l}R M \\
0 \\
2.05862 \\
5.6867 \\
10.0468 \\
12.0666 \\
13.0622 \\
13.5889\end{array}$ \\
\hline \multicolumn{6}{|c|}{ Variance decomposition of $R M$} \\
\hline Month & Standard error & $G Y$ & $C P$ & $B R$ & $R M$ \\
\hline $\begin{array}{r}1 \\
6 \\
12 \\
24 \\
36 \\
48 \\
60 \\
\end{array}$ & $\begin{array}{l}0.075581 \\
0.140144 \\
0.172550 \\
0.215647 \\
0.256578 \\
0.298296 \\
0.339387\end{array}$ & $\begin{array}{l}0 \\
4.82833 \\
9.83185 \\
16.3189 \\
20.3133 \\
22.8209 \\
24.3806 \\
\end{array}$ & $\begin{array}{l}0 \\
3.42472 \\
10.6703 \\
25.4689 \\
36.1984 \\
42.7248 \\
46.4778 \\
\end{array}$ & $\begin{array}{l}0.62107 \\
0.25099 \\
0.17049 \\
0.50491 \\
1.78088 \\
3.50981 \\
5.22628 \\
\end{array}$ & $\begin{array}{l}99.3789 \\
91.496 \\
79.3273 \\
57.7074 \\
41.7074 \\
30.9445 \\
23.9154 \\
\end{array}$ \\
\hline
\end{tabular}

$G Y$ : real output; $C P$ : consumer price level; $B R$ : bank rate; $R M$ : reserve money. 
Table 2. Variance decomposition for the composite model with a truncated sample

\begin{tabular}{|c|c|c|c|c|c|c|c|c|}
\hline \multicolumn{9}{|c|}{ Response of $G Y$} \\
\hline Month & Standard error & $G Y$ & $C P$ & $B L$ & $X R$ & $M 2$ & $B R$ & $R M$ \\
\hline $\begin{array}{r}1 \\
6 \\
12 \\
24 \\
36 \\
48 \\
60\end{array}$ & $\begin{array}{l}0.126568 \\
0.145212 \\
0.155524 \\
0.178783 \\
0.200973 \\
0.217330 \\
0.231932\end{array}$ & $\begin{array}{l}100 \\
88.9972 \\
78.4499 \\
59.7092 \\
47.5531 \\
40.6831 \\
35.8408\end{array}$ & $\begin{array}{l}0 \\
0.40382 \\
3.68215 \\
7.7282 \\
7.56146 \\
6.76495 \\
5.97162\end{array}$ & $\begin{array}{l}0 \\
0.01772 \\
0.05778 \\
4.33016 \\
12.5306 \\
18.4448 \\
21.9176\end{array}$ & $\begin{array}{l}0 \\
2.39005 \\
2.5118 \\
9.01098 \\
10.5965 \\
9.79906 \\
8.78839\end{array}$ & $\begin{array}{l}0 \\
4.9986 \\
5.55366 \\
6.05287 \\
5.46594 \\
5.58786 \\
6.14028\end{array}$ & $\begin{array}{l}0 \\
0.40715 \\
1.20002 \\
5.96018 \\
10.5178 \\
13.3136 \\
15.0565\end{array}$ & $\begin{array}{l}0 \\
2.78549 \\
8.54472 \\
7.20847 \\
5.77465 \\
5.40667 \\
6.28477\end{array}$ \\
\hline \multicolumn{9}{|c|}{ Response of $C P$} \\
\hline $\begin{array}{r}1 \\
6 \\
12 \\
24 \\
36 \\
48 \\
60\end{array}$ & $\begin{array}{l}\text { Standard error } \\
0.013956 \\
0.046473 \\
0.083148 \\
0.137077 \\
0.160414 \\
0.172351 \\
0.181295\end{array}$ & $\begin{array}{l}G Y \\
0.4792 \\
0.12692 \\
1.4681 \\
3.96805 \\
3.71715 \\
3.26477 \\
2.97764\end{array}$ & $\begin{array}{l}C P \\
99.5208 \\
78.5446 \\
51.49 \\
29.8407 \\
24.468 \\
21.9025 \\
19.9325\end{array}$ & $\begin{array}{l}B L \\
0 \\
3.14765 \\
7.17394 \\
16.7095 \\
23.9787 \\
28.5072 \\
31.0985\end{array}$ & $\begin{array}{l}X R \\
\quad 0 \\
15.6286 \\
29.3745 \\
28.74 \\
25.109 \\
22.8361 \\
20.9767\end{array}$ & $\begin{array}{l}0 \\
0.50971 \\
0.17985 \\
0.10506 \\
0.10531 \\
0.37441 \\
0.97151\end{array}$ & $\begin{array}{l}B R \\
0 \\
1.46601 \\
4.62699 \\
8.76834 \\
11.3679 \\
13.2559 \\
14.6828\end{array}$ & $\begin{array}{l}R M \\
0 \\
0.57655 \\
5.6866 \\
11.8684 \\
11.2539 \\
9.85916 \\
9.36032\end{array}$ \\
\hline \multicolumn{9}{|c|}{ Response of $B L$} \\
\hline $\begin{array}{l}\text { Month } \\
1 \\
6 \\
12 \\
24 \\
36 \\
48 \\
60\end{array}$ & $\begin{array}{l}\text { Standard error } \\
0.061116 \\
0.112898 \\
0.144458 \\
0.183652 \\
0.214536 \\
0.241363 \\
0.264883\end{array}$ & $\begin{array}{l}G Y \\
2.25829 \\
5.52293 \\
4.10393 \\
3.19664 \\
3.62075 \\
3.91385 \\
4.03579\end{array}$ & $\begin{array}{l}C P \\
0.19857 \\
2.53294 \\
1.78157 \\
1.44509 \\
1.64873 \\
1.78059 \\
1.85327\end{array}$ & $\begin{array}{l}B L \\
90.2722 \\
80.576 \\
78.8282 \\
72.3613 \\
61.5861 \\
53.247 \\
47.5869\end{array}$ & $\begin{array}{l}X R \\
0.01399 \\
1.51271 \\
2.4896 \\
1.79589 \\
1.62123 \\
1.45903 \\
1.31464\end{array}$ & $\begin{array}{l}M 2 \\
0.03068 \\
1.13583 \\
2.00075 \\
3.34287 \\
5.65369 \\
7.60075 \\
8.99576\end{array}$ & $\begin{array}{l}B R \\
0.09299 \\
0.84956 \\
5.57694 \\
10.8788 \\
12.488 \\
13.209 \\
13.7526\end{array}$ & $\begin{array}{l}R M \\
7.1333 \\
7.87006 \\
5.21904 \\
6.97945 \\
13.3816 \\
18.7898 \\
22.4611\end{array}$ \\
\hline \multicolumn{9}{|c|}{ Response of $X R$} \\
\hline $\begin{array}{l}\text { Month } \\
1 \\
6 \\
12 \\
24 \\
36 \\
48 \\
60\end{array}$ & $\begin{array}{l}\text { Standard error } \\
0.044089 \\
0.150086 \\
0.208144 \\
0.249072 \\
0.261629 \\
0.270823 \\
0.279642\end{array}$ & $\begin{array}{l}G Y \\
0.41431 \\
4.96644 \\
6.5994 \\
6.18497 \\
5.62408 \\
5.29833 \\
5.07369\end{array}$ & $\begin{array}{l}C P \\
14.0718 \\
15.4216 \\
12.2794 \\
10.1437 \\
9.50432 \\
8.92229 \\
8.37084\end{array}$ & $\begin{array}{l}B L \\
0 \\
6.55759 \\
13.7981 \\
22.9385 \\
26.9406 \\
28.815 \\
29.7261\end{array}$ & $\begin{array}{l}X R \\
85.5139 \\
66.815 \\
51.0453 \\
39.6472 \\
36.2663 \\
33.9814 \\
31.9085\end{array}$ & $\begin{array}{l}M 2 \\
0 \\
0.13971 \\
0.27603 \\
0.31664 \\
0.45737 \\
0.92018 \\
1.56142\end{array}$ & $\begin{array}{l}B R \\
0 \\
0.89385 \\
3.86841 \\
7.09144 \\
8.68215 \\
9.88385 \\
10.8526\end{array}$ & $\begin{array}{l}R M \\
\quad 0 \\
5.20574 \\
12.1333 \\
13.6776 \\
12.5252 \\
12.179 \\
12.5069\end{array}$ \\
\hline \multicolumn{9}{|c|}{ Response of $M 2$} \\
\hline $\begin{array}{l}\text { Month } \\
1 \\
6 \\
12 \\
24 \\
36 \\
48 \\
60\end{array}$ & $\begin{array}{l}\text { Standard error } \\
0.055066 \\
0.109179 \\
0.128239 \\
0.158546 \\
0.181069 \\
0.200763 \\
0.219489\end{array}$ & $\begin{array}{l}G Y \\
1.92636 \\
0.6548 \\
1.19103 \\
0.85575 \\
0.73459 \\
0.93304 \\
1.21924\end{array}$ & $\begin{array}{l}C P \\
0.28743 \\
1.81596 \\
7.08723 \\
6.11429 \\
4.81951 \\
3.92695 \\
3.33834\end{array}$ & $\begin{array}{l}B L \\
0 \\
7.52457 \\
14.4188 \\
25.9479 \\
32.2545 \\
34.1127 \\
34.0998\end{array}$ & $\begin{array}{l}X R \\
0.00352 \\
1.21604 \\
3.06702 \\
6.9906 \\
6.07727 \\
5.01824 \\
4.20601\end{array}$ & $\begin{array}{l}M 2 \\
95.4028 \\
81.1561 \\
60.4949 \\
42.1039 \\
34.0857 \\
29.888 \\
27.2372\end{array}$ & $\begin{array}{l}B R \\
2.3799 \\
1.71303 \\
3.13342 \\
10.7904 \\
15.022 \\
16.9727 \\
17.9386\end{array}$ & $\begin{array}{l}R M \\
0 \\
5.91948 \\
10.6076 \\
7.19716 \\
7.00647 \\
9.14839 \\
11.9608\end{array}$ \\
\hline \multicolumn{9}{|c|}{ Response of $B R$} \\
\hline $\begin{array}{l}\text { Month } \\
1 \\
6 \\
12 \\
24 \\
36 \\
48 \\
60\end{array}$ & $\begin{array}{c}\text { Standard error } \\
2.310353 \\
5.047104 \\
7.592677 \\
10.63528 \\
11.48259 \\
11.77244 \\
11.91782\end{array}$ & $\begin{array}{l}G Y \\
0.00072 \\
0.16952 \\
1.80112 \\
5.09523 \\
5.39437 \\
5.42576 \\
5.45687\end{array}$ & $\begin{array}{l}C P \\
0.02431 \\
25.4735 \\
24.6725 \\
17.5419 \\
16.3351 \\
16.0741 \\
15.9262\end{array}$ & $\begin{array}{l}B L \\
0 \\
0.62922 \\
2.04384 \\
4.5163 \\
4.95889 \\
4.86045 \\
4.75147\end{array}$ & $\begin{array}{l}X R \\
0.14773 \\
15.7219 \\
23.2621 \\
20.9502 \\
19.036 \\
18.4364 \\
18.1548\end{array}$ & $\begin{array}{l}M 2 \\
0 \\
7.20235 \\
6.99854 \\
7.25953 \\
7.83212 \\
8.1086 \\
8.26378\end{array}$ & $\begin{array}{l}B R \\
99.8273 \\
47.9679 \\
22.3638 \\
11.4689 \\
9.84913 \\
9.40063 \\
9.21899\end{array}$ & $\begin{array}{l}R M \\
\quad 0 \\
2.83565 \\
18.8581 \\
33.168 \\
36.5944 \\
37.694 \\
38.2279\end{array}$ \\
\hline \multicolumn{9}{|c|}{ Response of $R M$} \\
\hline Month & Standard error & $G Y$ & $C P$ & $B L$ & $X R$ & $M 2$ & $B R$ & $R M$ \\
\hline $\begin{array}{r}1 \\
6 \\
12 \\
24 \\
36 \\
48 \\
60\end{array}$ & $\begin{array}{l}0.078260 \\
0.12110 \\
0.136304 \\
0.152670 \\
0.166640 \\
0.180017 \\
0.193181\end{array}$ & $\begin{array}{l}1.19511 \\
1.09737 \\
1.06856 \\
0.97493 \\
0.84538 \\
0.89279 \\
1.05659\end{array}$ & $\begin{array}{l}1.22385 \\
1.12111 \\
1.80043 \\
2.30316 \\
2.10466 \\
1.81678 \\
1.59219\end{array}$ & $\begin{array}{l}20.7566 \\
17.1994 \\
14.4123 \\
14.8494 \\
19.0743 \\
22.1946 \\
24.002\end{array}$ & $\begin{array}{l}3.12052 \\
1.78105 \\
3.72633 \\
7.21981 \\
6.91603 \\
6.09373 \\
5.32603\end{array}$ & $\begin{array}{l}11.4659 \\
18.0151 \\
18.6833 \\
18.143 \\
16.9618 \\
16.2624 \\
15.8866\end{array}$ & $\begin{array}{c}0.84125 \\
0.76545 \\
2.18612 \\
7.90619 \\
11.9046 \\
14.1667 \\
15.5339\end{array}$ & $\begin{array}{l}61.3968 \\
60.0205 \\
58.123 \\
48.6036 \\
42.1932 \\
38.573 \\
36.6028\end{array}$ \\
\hline
\end{tabular}

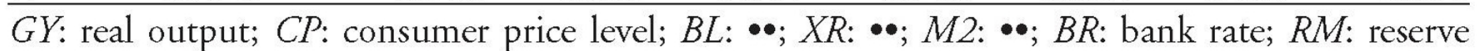
money. 